\title{
CFD simulation of cross-ventilation for a generic isolated building: impact of computational parameters
}

\author{
R. Ramponi ${ }^{(\mathrm{a}, \mathrm{b})} *$, B. Blocken ${ }^{(\mathrm{b})}$
}

(a) Building Environment Science \& Technology Department, Politecnico di Milano, via Bonardi 3, 20133 Milano, Italy

(b) Building Physics and Systems, Eindhoven University of Technology, P.O. box 513, 5600 MB Eindhoven, the Netherlands

- Extensive literature review on numerical cross-ventilation studies in overview table.

- Detailed sensitivity analysis for CFD simulations of a cross-ventilated building model.

- The SST k- $\omega$ turbulence model shows the best agreement with PIV measurements.

- The turbulent kinetic energy strongly influences the convergence and the results.

- The prediction of the outdoor standing vortex largely affects the indoor airflow.

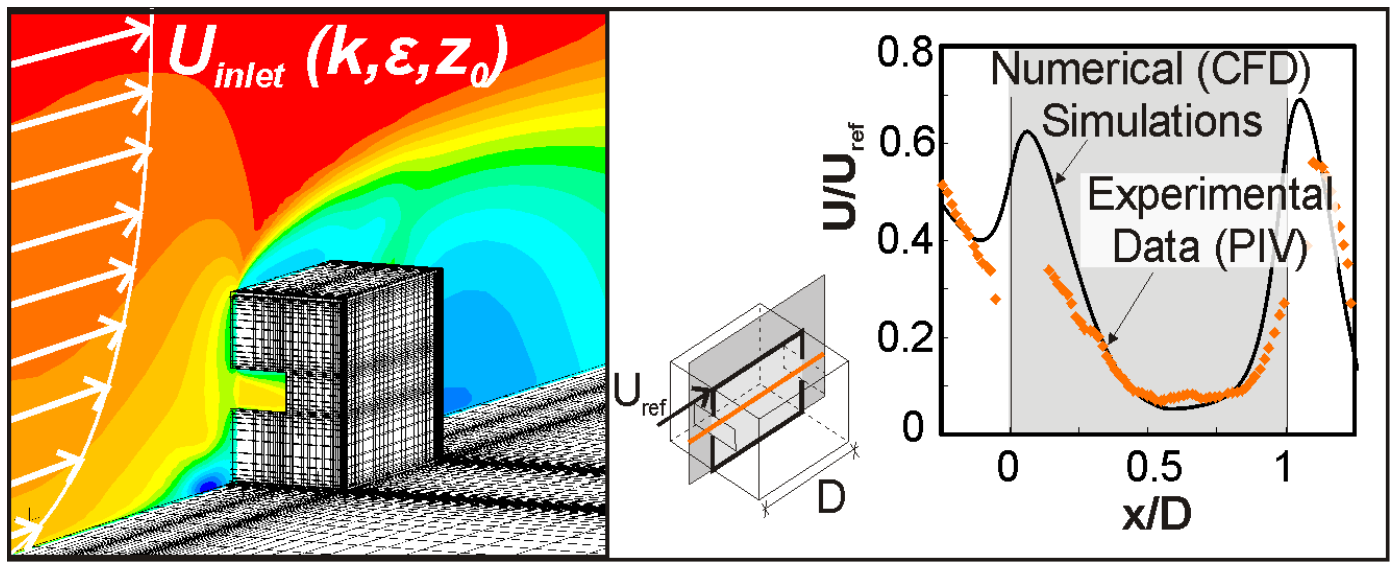

* Corresponding author: Rubina Ramponi, Building Physics and Systems, Eindhoven University of Technology, P.O. Box 513, 5600 MB Eindhoven, the Netherlands. Tel.: +31 (0)40 247 5613, Fax +31 (0)40 2438595 E-mail address: r.ramponi@tue.nl 


\title{
CFD simulation of cross-ventilation for a generic isolated building: impact of computational parameters
}

\author{
R. Ramponi ${ }^{(\mathrm{a}, \mathrm{b})} *$, B. Blocken ${ }^{(\mathrm{b})}$ \\ (a) Building Environment Science \& Technology Department, Politecnico di Milano, via Bonardi 3, 20133 \\ Milano, Italy \\ (b) Building Physics and Systems, Eindhoven University of Technology, P.O. box 513, 5600 MB Eindhoven, \\ the Netherlands
}

\begin{abstract}
Accurate CFD simulation of coupled outdoor wind flow and indoor air flow is essential for the design and evaluation of natural cross-ventilation strategies for buildings. It is widely recognized that CFD simulations can be very sensitive to the large number of computational parameters that have to be set by the user. Therefore, detailed and generic sensitivity analyses of the impact of these parameters on the simulation results are important to provide guidance for the execution and evaluation of future CFD studies. A detailed review of the literature indicates that there is a lack of extensive generic sensitivity studies for CFD simulation of natural cross-ventilation. In order to provide such a study, this paper presents a series of coupled 3D steady RANS simulations for a generic isolated building. The CFD simulations are validated based on detailed wind tunnel experiments with Particle Image Velocimetry. The impact of a wide range of computational parameters is investigated, including the size of the computational domain, the resolution of the computational grid, the inlet turbulent kinetic energy profile of the atmospheric boundary layer, the turbulence model, the order of the discretization schemes and the iterative convergence criteria. Specific attention is given to the problem of oscillatory convergence that was observed during some of these coupled CFD simulations. Based on this analysis, the paper identifies the most important parameters. The intention is to contribute to improved accuracy, reliability and evaluation of coupled CFD simulations for cross-ventilation assessment.
\end{abstract}

Keywords: Computational Fluid Dynamics (CFD); building; natural ventilation; air flow; sensitivity study; parametric study

\section{Introduction}

Natural ventilation is an important factor in the development of sustainable and healthy indoor environments (e.g. [1-8]). It is driven by wind or buoyancy, or - most often - a combination of both (e.g. [8-13]). In the past decades, a lot of research efforts contributed to the evaluation of the natural ventilation performance of buildings. A comprehensive review on methods for ventilation performance prediction for buildings was provided by Chen [5]. Other reviews were provided by Reichrath and Davies [14], Karava et al. [15,16], Norton and Sun [17] and Norton et al. [18].

Ventilation performance can be assessed by experiments (e.g. [6,7,9,10,13,19-29]), analytical and/or semiempirical formulae (e.g. [9-11,13,15,30-34]), simulations with zonal and multizone network models (e.g. [3538]) and Computational Fluid Dynamics (CFD) models (e.g. [8,21-24,39-45]). CFD has a number of clear advantages compared with the other approaches (e.g. $[8,46])$ : $(1)$ as opposed to most experimental techniques including Particle Image Velocimetry (PIV), CFD provides whole-flow field data, i.e. data on the relevant parameters in every point of the computational domain; (2) CFD avoids the sometimes incompatible similarity requirements in reduced-scale testing because simulations can be performed at full scale; and (3) CFD allows

* Corresponding author: Rubina Ramponi, Building Physics and Systems, Eindhoven University of Technology, P.O. Box 513, 5600 MB Eindhoven, the Netherlands. Tel.: +31 (0)40 247 5613, Fax +31 (0)40 2438595

E-mail address: r.ramponi@tue.nl 
full control over the boundary conditions and easily and efficiently allows parametric studies to be performed. Chen [5] additionally mentions that CFD models are currently most popular and particularly suited for studying indoor air quality and natural ventilation, as these are difficult to predict with other models. For these reasons, many studies on evaluating and optimizing the natural ventilation potential of buildings have employed CFD.

In CFD simulations of cross-ventilation involving large openings, a major issue of concern is the accurate modeling of the interaction between the outdoor wind flow around the buildings and the indoor air flow inside the buildings, which interact with each other at the ventilation openings. A distinction can be made between a coupled and a decoupled approach. In the coupled approach, there is a single computational geometry and computational domain, that includes both the outside and the inside environment of the building (Fig. 1a). In this approach, the ventilation openings are considered open, the outdoor wind flow and indoor air flow are solved within the same computational domain and the interaction (coupling) between the outdoor wind flow and indoor air flow is resolved in detail using the appropriate governing equations (e.g. [8,21,47]). Contrary to this, in the decoupled approach, there are two different computational geometries and two different computational domains: one for the outdoor environment and one for the indoor environment of the building (Fig. 1b). In this approach, the wind flow simulation is conducted for the building as a sealed body, i.e. the openings are "closed". This simulation yields the pressure coefficients at the positions of the openings and these coefficients are subsequently used as boundary conditions for the CFD simulation of the indoor air flow (e.g. [48]).

A detailed review of the literature by the present authors indicates that, by far, most CFD research on windinduced cross-ventilation has applied the coupled approach. An extensive, but not necessarily exhaustive, overview of coupled outdoor-indoor CFD studies is given in Table 1. Table 1 also indicates the type of study (generic or applied), the type of building and surroundings (isolated, building group, urban), the turbulence modeling approach (RANS, LES, DES) and turbulence models used, whether validation was performed, and whether and for which parameters a sensitivity analysis was performed.

The main reason for the extensive use of the coupled approach is the knowledge that, in case of large ventilation openings, the decoupled approach can introduce important errors. Indeed, the so-called sealed-body assumption in the decoupled approach implies that the pressure distribution on the building envelope is not affected by the presence of the openings [20,21,25]. It assumes that the turbulent kinetic energy is dissipated at the windward opening and that the effect of the dynamic pressure on the air flow passing through the opening is negligible [20,25,28,39,73,92]. However, Murakami et al. [20], Kato et al. [21], Sandberg [93], Karava et al. [16,28], Kobayashi et al. [71,73] correctly pointed out that in case of wind flow through large ventilation openings, the turbulent kinetic energy is rather preserved and the sealed-body assumption is therefore not longer valid. A virtual stream-tube model was introduced to explain the direct connection between the inlet and outlet openings $[20,21,71,73,93]$.

The accuracy and reliability of CFD simulations are a main concern [5,45]. They impose the need for (1) validation studies and (2) sensitivity studies including solution verification. Validation of coupled CFD simulations can be performed with high-quality wind tunnel experiments. The experimental equivalent of a coupled CFD simulation is a wind tunnel experiment of combined outdoor wind flow and indoor air flow. In this respect, Particle Image Velocimetry (PIV) is particularly suitable because it allows simultaneous measurement of the outdoor wind flow and the indoor air flow and it provides detailed spatial information of the velocity field in a plane of interest. The application of PIV to wind-induced natural ventilation is a quite recent development. Lee et al. [58], Kobayashi et al. [73], Karava et al. [28] have provided extensive PIV measurement data for generic isolated building models.

Accuracy and reliability also impose the need for detailed sensitivity studies. Indeed, CFD simulation results can be very sensitive to the large number of computational parameters that have to be set by the user. Therefore, detailed and generic sensitivity analyses are important to provide guidance for the execution and evaluation of future CFD studies. Strong support for CFD simulation of wind flow around buildings in general has been provided by the recent establishment of best practice guidelines, e.g. [94-98]. Similarly, best practice guidelines were developed for indoor air flow [99]. While these documents provide very valuable general information, they were not specifically focused on wind-induced cross-ventilation and therefore do not provide specific guidelines for this case. Establishing specific guidelines requires detailed and systematic sensitivity analyses for crossventilation. Table 1 indicates that most previous CFD studies on coupled cross-ventilation did include some type of sensitivity analysis, but that this analysis most often focused on the influence of the grid resolution, the building geometry (including ventilation openings) and the turbulence model. The most extensive sensitivity study for cross-ventilation so far was provided by Meroney [72].

In this paper, we provide a detailed and extensive sensitivity analysis for coupled CFD simulations of windinduced cross-ventilation. The paper presents a series of 3D CFD steady RANS simulations for a generic isolated building. The simulations are validated based on detailed wind tunnel experiments with PIV by Karava et al. [28]. The impact of a wide range of computational parameters is investigated, including the size of the computational domain, the resolution of the computational grid, the inlet turbulent kinetic energy profile of the 
atmospheric boundary layer, the turbulence model, the order of the discretisation schemes and the iterative convergence criteria.

Section 2 briefly outlines the PIV measurements by Karava et al. [28]. Section 3 presents the computational settings and parameters and the results for the reference case. Section 4 contains the sensitivity analysis. Finally, the results are discussed in Section 5 and the main conclusions are presented in Section 6.

\section{Description of the experiments}

Detailed PIV measurements of wind-induced cross-ventilation for generic isolated building models were conducted by Karava et al. [28] in the Concordia University Boundary Layer Wind Tunnel [100]. This opencircuit wind tunnel is $12 \mathrm{~m}$ long and has a test section of $1.8 \times 1.8 \mathrm{~m}^{2}$. A small extension with glass window was constructed for accommodating the PIV measurements downstream the turntable near the wind tunnel outlet. Building models with flat roof and with different openings (area and position) were built from $2 \mathrm{~mm}$ cast transparent polymethylmethacrylate (PMMA) sheet at a scale of 1:200. The buildings had dimensions W x D x $\mathrm{H}=100 \times 100 \times 80 \mathrm{~mm}^{3}$ (reduced scale) corresponding to full-scale dimensions $\mathrm{W} \times \mathrm{D} \times \mathrm{H}=20 \times 20 \times 16 \mathrm{~m}^{3}$. Different positions and sizes of ventilation openings were evaluated. The size of the openings was expressed as wall porosity, defined as the ratio between the opening area and the area of the wall. The openings had a fixed height of $18 \mathrm{~mm}$ (3.6 m full scale) and a variable width, providing a wall porosity of 5, 10 and 20\%. Three opening positions were considered: bottom, center and top, with the center of the opening at $\mathrm{h}=20 \mathrm{~mm}, 40 \mathrm{~mm}$ and $57 \mathrm{~mm}$, respectively. In this paper, we focus on the model with both openings at the center of the two opposite walls and with a wall porosity of $10 \%$ (Fig. 2).

The model was placed in the extension of the wind tunnel with the openings perpendicular to the approaching flow. An open-terrain roughness profile was reproduced by covering the floor with extruded polystyrene (XPS) cubes upstream and a carpet along the rest of the wind tunnel. The resulting reduced-scale aerodynamic roughness length was $\mathrm{z}_{0}=0.025 \mathrm{~mm}$ corresponding to $0.005 \mathrm{~m}$ in full scale [101]. The mean velocity and turbulence intensity profiles were measured in the test section, i.e. at the building position but without the building present, using a hot-film probe. Measuring at the turntable position yields the incident profiles for CFD simulation, which is very important for a reliable validation study [102,103]. A reference mean wind speed $U_{\text {ref }}=$ $6.97 \mathrm{~m} / \mathrm{s}$ and a reference turbulence intensity of $10 \%$ were measured at building height. The turbulence intensity was about $17 \%$ near ground level $(12 \mathrm{~mm})$ and $5 \%$ at gradient height $(738 \mathrm{~mm})$. The PIV measurements were conducted in a horizontal plane at mid-height through the openings $(\mathrm{h}=0.04 \mathrm{~m})$ and in the vertical plane of symmetry. For more information, the reader is referred to Karava et al. [28]. The results will be shown together with the CFD simulation results in the next sections.

\section{CFD simulations: reference case}

In this section, computational settings and parameters for the reference case are outlined, and the results for this case are presented. Later, these settings and parameters will be systematically modified for the sensitivity study.

\subsection{Computational domain and grid}

The dimensions of the computational domain were chosen based on the best practice guidelines by Franke et al. [96] and Tominaga et al. [98], apart from the upstream length, which was reduced to 3 times the height of the building to limit the development of unintended streamwise gradients [97,104]. The resulting dimensions of the domain were $\mathrm{W} \times \mathrm{D} \times \mathrm{H}=0.9 \times 1.54 \times 0.48 \mathrm{~m}^{3}$ (reduced scale), which corresponds to $180 \times 308 \times 96 \mathrm{~m}^{3}$ in full scale. The computational grid was fully structured and was created using the surface-grid extrusion technique by van Hooff and Blocken [8]. The grid is shown in Figure 3. A maximum stretching ratio of 1.2 controls the cells located in the immediate surroundings of the building model, where the transition from the small thickness of the walls $(2 \mathrm{~mm})$ to the larger scales in the domain occurs. The grid has 575,247 hexahedral cells. The grid resolution resulted from a grid-sensitivity analysis that will be outlined in section 4.2.

\subsection{Boundary conditions}

The inlet boundary conditions used in the simulations were based on the measured incident vertical profiles of mean wind speed and turbulence intensity. The inlet wind velocity profile was defined according to the logarithmic law with $\mathrm{z}_{0}=0.025 \mathrm{~mm}$ (Eq. 1), where $\mathrm{u}^{*}{ }_{\mathrm{ABL}}$ is the ABL friction velocity, $\kappa$ the von Karman constant (0.42) and $\mathrm{z}$ the height coordinate. The turbulent kinetic energy $\mathrm{k}$ was calculated from the mean wind speed and the measured turbulence intensity using Eq. 2, where $\mathrm{I}_{\mathrm{u}}$ is the streamwise turbulence intensity and $a$ is a parameter in the range between 0.5 and 1.5 , as will be explained later, in section 4.3. Different studies have used different values for this parameter. Note that Tominaga et al. [98] recommend $a=1$, which is also the value 
we chose for the reference case. The turbulence dissipation rate $\varepsilon$ was given by Eq. 3 and the specific dissipation rate $\omega$ by Eq. 4 , where $C_{\mu}$ is an empirical constant taken equal to 0.09 .

$$
\begin{aligned}
& U(z)=\frac{u_{A B L}^{*}}{\kappa} \ln \left(\frac{z+z_{0}}{z_{0}}\right) \\
& k(z)=a\left(I_{u}(z) U(z)\right)^{2} \\
& \varepsilon(z)=\frac{u_{A B L}^{* 3}}{\kappa\left(z+z_{0}\right)} \\
& \omega(z)=\frac{\varepsilon(z)}{C_{\mu} k(z)}
\end{aligned}
$$

For the ground surface, the standard wall functions by Launder and Spalding [105] with roughness modification by Cebeci and Bradshaw [106] are used. The values of the roughness parameters, i.e. the sand-grain roughness height $\mathrm{k}_{\mathrm{S}}(\mathrm{m})$ and the roughness constant $\mathrm{C}_{\mathrm{S}}$, were determined using their consistency relationship with the aerodynamic roughness length $\mathrm{z}_{0}$ derived by Blocken et al. [97] (Eq. 5). The selected values are $\mathrm{k}_{\mathrm{S}}=0.28 \mathrm{~mm}$ and $\mathrm{C}_{\mathrm{S}}=0.874$. Standard wall functions are also used at the building surfaces, but with zero roughness height $\left(\mathrm{k}_{\mathrm{S}}\right.$ $=0)$.

$k_{S}=\frac{9.793 z_{0}}{C_{S}}$

Zero static pressure is applied at the outlet plane and symmetry conditions, i.e. zero normal velocity and zero normal gradients of all variables, at the top and lateral sides of the domain [107]. As recommended by Blocken et al. $[97,103,104]$, a simulation was made in an empty computational domain to assess the extent of unintended streamwise gradients (i.e. horizontal inhomogeneity) in the vertical profiles of mean wind speed and the turbulence parameters. Figure 4 illustrates the inlet and the incident profiles, indicating only minor streamwise gradients, which is an important quality criterion for the simulations.

\subsection{Solver settings}

The simulations were performed with the commercial CFD code Fluent 6.3.26 [107]. The 3D steady RANS equations were solved in combination with the shear-stress transport (SST) k- $\omega$ model [88]. The SIMPLE algorithm was used for pressure-velocity coupling, pressure interpolation was second order and second-order discretization schemes were used for both the convection terms and the viscous terms of the governing equations. Convergence was assumed to be obtained when all the scaled residuals [107] leveled off and reached a minimum of $10^{-6}$ for $\mathrm{x}, \mathrm{y}$ and $\mathrm{z}$ momentum, $10^{-5}$ for $\mathrm{k}$ and $10^{-4}$ for $\omega$ and continuity. Fig. 5a shows the scaled residuals as a function of the number of iterations. The simulations showed oscillatory convergence. Note however that this apparently minor oscillatory convergence can actually be the result of very strong local oscillatory behavior in the flow field, because the scaled residuals provide an overall value averaged over all cells in the computational domain. Fig. 5b shows the local ratio of streamwise wind speed $U$ to reference wind speed $U_{\text {ref }}$ in three points along the centerline connecting the mid-points of the two openings. It indicates that the wind speed is relatively constant in point 1 , that it shows some fluctuations in point 2 , and that it shows very large fluctuations in point 3 . Therefore, in this paper, the oscillatory behavior of the results was monitored over 10000 iterations and the calculated variables were averaged when necessary.

\subsection{Results and comparison with PIV experiments}

The results for the reference case were compared with the PIV measurements by Karava et al. [28]. Figs. 6a-b show the velocity vector field in the vertical centerplane obtained with the PIV measurements and the CFD simulations. The simulations reproduce the main features of the flow, such as the standing vortex upstream of the building, which will be shown later to be very important, the contraction and expansion of the indoor flow and the separation zone on the roof. Figs. 6c-d show the PIV and CFD velocity vector field in the horizontal plane at 
$\mathrm{h}=0.04 \mathrm{~m}$ (note: only half is shown due to symmetry). The figures show a close qualitative agreement between the PIV measurements and the CFD simulation, both in the outdoor wind flow and indoor air flow.

In Fig. 7, the comparison of the streamwise wind speed ratio $\mathrm{U} / \mathrm{U}_{\text {ref }}$ along the centerline confirms the good match between numerical and experimental results. The numerical model tends to overestimate the mean velocity around the opening, where the PIV measurements cannot provide accurate predictions due to reflections and shading effects [28]. Nevertheless, both the approaching wind flow and the indoor air flow are described very accurately by the model as well as the flow downstream the outlet opening.

\section{CFD simulations: sensitivity analysis}

A systematic and detailed sensitivity analysis was conducted based on the reference case, by systematically varying a single parameter compared to the reference case and evaluating the impact of this change on the simulation results. The parameters tested are the size of the computational domain (Section 4.1), the resolution of the computational grid (Section 4.2), the inlet turbulent kinetic energy of the atmospheric boundary layer (Section 4.3), the turbulence model (Section 4.4), the discretization schemes (Section 4.5) and the convergence criteria (Section 4.6). Table 2 provides an overview of the computational parameters for the sensitivity analysis, with indication of the reference case.

\subsection{Impact of size of computational domain}

Only the cross-section (width and height) of the computational domain was varied. The upstream and downstream length of the domain remained fixed at $3 \mathrm{H}$ and $15 \mathrm{H}$, respectively, with $\mathrm{H}$ the building height. The parameter that was varied is the distance $d$ (see Fig. 8). The height $H_{D}$ of the domain is $H_{D}=H+d$, while the width $\mathrm{W}_{\mathrm{D}}$ of the domain is $\mathrm{W}_{\mathrm{D}}=\mathrm{W}+2 \mathrm{~d}$, with $\mathrm{W}$ the width of the building. Note that an often used parameter to indicate the size of the computational domain is the blockage ratio (B.R.), i.e. the ratio between the frontal area of the model facade and the cross-section of the computational domain. Guidelines by Franke et al. [96] and Tominaga et al. [98] suggest a minimum distance (d) equal to 5 times the height $(\mathrm{H})$ to avoid the interference of the domain size on the numerical simulation results. Thus, a distance $d=5 \mathrm{H}(\mathrm{B} . \mathrm{R} .=2 \%)$ was applied in the reference case and then reduced to 4 H $($ B.R. $=3 \%), 3$ H $($ B.R. $=4 \%), 2$ H $($ B.R. $=8 \%)$ and H $($ B.R. $=19 \%)$. Fig. 8 shows that the reduction of the cross-section of the computational domain influences the indoor air speed, causing a maximum local increase of $26 \%(\mathrm{x} / \mathrm{D}=0.5)$ for $\mathrm{d}=4 \mathrm{H}$, of $50 \%(\mathrm{x} / \mathrm{D}=0.5)$ for $\mathrm{d}=3 \mathrm{H}$ and of $134 \%$ $(\mathrm{x} / \mathrm{D}=0.5)$ for $\mathrm{d}=2 \mathrm{H}$. A considerable increase in indoor air speed, locally of up to $500 \%(\mathrm{x} / \mathrm{D}=0.5)$, is shown when the cross-section is strongly reduced $(\mathrm{d}=\mathrm{H})$. A comparison of the ventilation flow rates reveals a similar trend: the flow rate increases by $1.2 \%, 2.2 \%, 5.1 \%$ and $21.1 \%$ when the distance $\mathrm{d}$ is reduced to $4 \mathrm{H}, 3 \mathrm{H}, 2 \mathrm{H}$ and $\mathrm{H}$ respectively.

\subsection{Impact of computational grid resolution}

In addition to the reference grid (grid C) with 575,247 cells, two coarser grids were constructed, consisting of 314,080 (grid B) and 144,696 cells (grid A). The grids were obtained by coarsening the reference (fine) grid with twice about a factor 2. The three grids are illustrated in Fig. 9, and the results on the three grids are shown in Fig. 10a. For uniform reporting of the grid-convergence study, we adopted the concept of the grid-convergence index (GCI) by Roache $[108,109]$. The results show that grid sensitivity is most pronounced for the indoor area behind the inlet $(\mathrm{x} / \mathrm{D}=0-0.6)$ and behind the outlet $(\mathrm{x} / \mathrm{D}=1-1.25)$. The analysis also shows that the reference (fine) grid that was used for the reference case is a suitable grid. The difference in the ventilation flow rates through the inlet openings is about $1.0 \%$ between the reference (fine) grid and grid B, while it is $7.5 \%$ between the reference (fine) grid and grid A.

\subsection{Impact of inlet turbulent kinetic energy}

According to literature, the turbulent kinetic energy profile at the inlet can be estimated from the measured wind velocity and turbulence intensity profiles following Eq. 2. In fact, to determine the turbulent kinetic energy, the standard deviations of the turbulent fluctuations in the three directions should be known (Eq. 6):

$k=\frac{1}{2}\left(\sigma_{u}^{2}+\sigma_{v}^{2}+\sigma_{w}^{2}\right)$

Often however, only $\sigma_{u}{ }^{2}$ is measured, which is related to the longitudinal turbulence intensity: $I_{u}=\sigma_{u} / U$. For the other two components, different assumptions can be made, which yield different values of the turbulent kinetic energy: 
Assumption 1: $\sigma_{\mathrm{u}}{ }^{2}>>\sigma_{\mathrm{v}}{ }^{2} \approx \sigma_{\mathrm{w}}{ }^{2}$, which yields:

$k=\frac{1}{2}\left(I_{u} U\right)^{2}$

Assumption 2: $\sigma_{\mathrm{u}}{ }^{2} \approx{\sigma_{\mathrm{v}}}^{2}+{\sigma_{\mathrm{w}}}^{2}$, which yields:

$k=\left(I_{u} U\right)^{2}$

Assumption 3: $\sigma_{\mathrm{u}}{ }^{2} \approx \sigma_{\mathrm{v}}{ }^{2} \approx \sigma_{\mathrm{w}}{ }^{2}$, which yields:

$k=\frac{3}{2}\left(I_{u} U\right)^{2}$

In summary, the relationship between the turbulent kinetic energy $\mathrm{k}$, the longitudinal turbulence intensity $\mathrm{I}_{\mathrm{u}}$ and the wind speed $U$ is given by:

$k=a\left(I_{u} U\right)^{2}$

with a equal to $0.5,1$ or 1.5 . These different values for a have been used in CFD studies in the past. Note however that the best practice guidelines by Tominaga et al. [98] suggest using $\mathrm{a}=1$.

In this sensitivity study, we have used these three values for a. Note that Eq. (4) shows that the value of $\mathrm{k}$ also affects the specific dissipation rate $\omega$ used by the $\mathrm{k}-\omega$ models. Different profiles of $\mathrm{k}$ and $\omega$ were defined by varying the parameter a. Results were compared with the reference case $(\mathrm{a}=1)$ both in terms of inlet and incident profiles in the empty domain (Fig. 11) and of streamwise wind speed ratio along the centerline of the openings (Fig. 12). As displayed in Figure 11, the increased turbulent kinetic energy profiles at the inlet are not significantly affecting the horizontal homogeneity of the approaching flow. Only some small streamwise changes are noted for the turbulent kinetic energy profiles themselves. However, Fig. 12 shows that varying the inlet turbulent kinetic energy with the parameter a has a very large impact on the wind speed ratio along the centerline. To the best of our knowledge, this large impact has not been demonstrated before. Three different zones can be distinguished. In the approach flow, upstream of the inlet opening, the impact is limited. $U / \mathrm{U}_{\text {ref }}$ decreases by $7 \%$ when a is increased from 1 to 1.5 , and $\mathrm{U} / \mathrm{U}_{\text {ref }}$ increases by $12 \%$ when a is decreased from 1 to 0.5. Similarly small changes are observed downstream of the outlet opening. Higher deviations however are found indoor. In the centre of the room $(x / D=0.5), U / \mathrm{U}_{\text {ref }}$ increases by up to a factor 4 when a is increased from 1 to 1.5 , and decreases by down to a factor 1.5 when a is decreased from 1 to 0.5 . Clearly, for this experiment, a $=1$ closely represents the actual approach-flow conditions, and $\mathrm{a}=0.5$ and $\mathrm{a}=1.5$ lead to large deviations from the measured mean velocity. The ventilation flow rate shows a corresponding decrease of $2.4 \%$ when a is decreased from 1 to 0.5 , and an increase of $4.5 \%$ when a is increased from 1 to 1.5 .

It is interesting to investigate the effect of inlet turbulent kinetic energy on the oscillatory convergence behavior that was observed earlier. This effect is shown in Figure 13, for three selected points along the centerline. The wind speed ratio upstream of the inlet opening (Point 1 in Fig. 13) remains constant throughout iterations 9000 to 9900 . The wind speed ratio in point 2 however shows significant oscillations which however decrease with increasing inlet turbulent kinetic energy. Finally, also the fluctuations in point 3 are damped when turbulent kinetic energy increase. This behavior is attributed to the fact that the flow is intrinsically unsteady, but is forced into a steady solution by the application of the steady RANS approach. The effect of turbulent kinetic energy is increased mixing of momentum, which also smoothens out the instabilities. This is clearly observed in Fig. 13. This means that special care should be applied when extracting results from steady RANS results of intrinsically unsteady flow phenomena. In the present study, we performed averaging over a large number of iterations to obtain a reliable steady value of the solution variables.

\subsection{Impact of turbulence model}

3D steady RANS simulations are made with different turbulence models:

- $\quad$ standard k- $\varepsilon$ model (Sk- $\varepsilon$ ) [79];

- realizable k- $\varepsilon$ model (Rk- $\varepsilon$ ) [82];

- Renormalization Group k- $\varepsilon$ model (RNG k- $\varepsilon$ ) [80,81];

- $\quad$ standard k- $\omega$ model (Sk- $\omega)$ [87];

- $\quad$ shear-stress transport k- $\omega$ model (SST k- $\omega$ ) [88]; 
- $\quad$ Reynolds Stress Model (RSM) [89].

The effects of the turbulence models on the indoor air flow are illustrated in terms of streamwise wind speed ratio along the centerline of the openings (Fig. 14), contours of streamwise wind speed in the vertical centerplane (Fig. 15) and the velocity vector field in the vertical centerplane (Fig. 16). The impact of the turbulence models on the ventilation flow rates was also computed. Fig. 14, which also shows the comparison with the PIV measurements, indicates that the SST k- $\omega$ model (Ref. case) is clearly superior, followed by the RNG k- $\varepsilon$ model, which also provides a fairly good performance. The discrepancies by the other models are very large. In fact, Fig. 14a shows that the indoor streamwise wind speed obtained with the other k- $\varepsilon$ models is up to 6 times higher (at $\mathrm{x} / \mathrm{D}=0.75$ ) than the one obtained using the SST k- $\omega$ model (Ref. case). A similar pattern can be observed in Fig. 14b, which shows that the RSM and the standard k- $\omega$ models tend to overpredict the experimental values by up to 9 times $(\mathrm{x} / \mathrm{D}=0.6)$. Note that in several previous studies, authors pointed out the superior performance of the RNG k- $\varepsilon$ model for indoor air flow modeling, especially compared to the standard k- $\varepsilon$ model $[41,50,64,71]$. This is to a large degree confirmed by our study. However, in our study, the SST k- $\omega$ model even outperforms the RNG k- $\varepsilon$ model. Fig. 15 more clearly shows the differences in results obtained with different turbulence models. It indicates that the main discrepancies are related to the direction of the jet entering the building model. Fig. 16 shows that the jet direction is closely related to the reproduction of the standing vortex upstream of the building model. This vortex is most accurately reproduced by the SST k- $\omega$ model (see also Fig. 6a-b), somewhat less accurately by the RNG k- $\varepsilon$ model, and poorly by the other models. This is directly in line with the disagreement with the PIV measurements in Fig. 14. The strong relation of the indoor air flow with the reproduction of the standing vortex upstream the building is confirmed by the variation of the ventilation flow

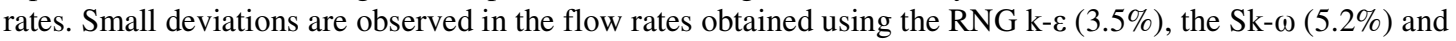
the Sk- $\varepsilon(5.7 \%)$ turbulence models when compared to the SST k- $\omega$ model. However, these deviations increase by $15.2 \%$ and $16.0 \%$ for the Rk- $\varepsilon$ and the RSM model, respectively.

\subsection{Impact of order of discretization scheme}

While CFD best practice guidelines consistently stress the importance of at least discretization schemes of second-order accuracy [96,98,110], still many studies in building engineering are performed with first-order schemes. Indeed, first-order schemes provide the sometimes necessary numerical diffusion to achieve convergence with unstructured computational grids that include tetrahedral and/or pyramid cells, rather than hexahedral and prismatic cells [8]. However, the numerical diffusion by first-order schemes also decreases flow gradients, as shown in Fig. 17, which indeed shows that for this situation accurate results can not be obtained with first-order discretization schemes. The comparison between the ventilation flow rates indicates an increase of $10.1 \%$ when the first-order scheme is used.

\subsection{Impact of level of iterative convergence}

There is no clear consensus in literature about the level of iterative convergence, apart from the statement that convergence of critical variables should be monitored and confirmed. Care should be taken to avoid convergence criteria that are too lenient. Fluent 6.3 for example has the default setting of scaled residuals for convergence at $10^{-3}$, although the Fluent code manual indeed correctly warns that tighter criteria might be needed [107]. Fig. 18 confirms that this is the case, and that further iterations, beyond the $10^{-3}$ threshold, are needed to achieve a converged solution that shows a good agreement with the experimental data. The difference in the ventilation flow rates is small: an increase of $1.5 \%$ for convergence at $10^{-3}$ and a reduction of $1.1 \%$ for convergence at $10^{-4}$.

\section{Discussion}

This paper has provided a detailed and systematic analysis of the impact of several computational parameters on the numerical simulation results of wind-induced cross-ventilation of a generic isolated building. While this study has provided several new insights, it is also important to mention the limitations of this study:

- The study was only performed for a single isolated and simplified building geometry and did not investigate the influence of building geometry and position and size of the ventilation openings.

- The study was only performed for a given aerodynamic roughness length and for the corresponding incident atmospheric boundary layer profiles of mean wind speed, turbulent kinetic energy and turbulence dissipation rate.

- The study was only performed for wind direction perpendicular to the windward facade.

- The study only focused on the mean air speed as the parameter of primary importance. It did not evaluate outdoor and indoor turbulence intensities and turbulence diffusivities, which are particularly important in dispersion of indoor contaminants. 
- Concerning the size of the computational domain, only the cross-section (width and height) was varied, while the upstream and downstream length remained fixed at $3 \mathrm{H}$ and $15 \mathrm{H}$ respectively, with $\mathrm{H}$ the building height.

In spite of these shortcomings, the present study has provided new and valuable insights. It has indicated the important influence of the turbulence model, the order of the discretization schemes, the convergence criteria and especially of the incident turbulent kinetic energy profiles on the simulation results. In particular, to the best of our knowledge, the important influence of the turbulent kinetic energy profile has not been reported in previous studies. A related issue is the impact of the upstream length of the computational domain on the simulation results, i.e. the distance between the inlet plane and the windward facade of the building. As mentioned in section 3.1, we limited this distance to $3 \mathrm{H}$ to limit the development of unintended streamwise gradients and the related artificial reduction in the approach-flow turbulent kinetic energy, also called horizontal inhomogeneity [97,104]. Although Fig. 4 showed that this reduction was indeed limited in the present study, it is important to document the potential changes and their impact on the simulation results.

As a result, future work should focus on:

- Exploring the impact of building geometry, position and size of the ventilation openings and the impact of surrounding buildings on the simulation results.

- Exploring the influence of different upstream roughness and approach-flow profiles.

- Exploring the influence of different wind directions (or building orientations).

- Exploring not only the impact of computational parameters on the mean air speed but also on the outdoor and indoor turbulence intensities and turbulent diffusivities on the spreading of indoor contaminants.

- Exploring the impact of upstream distance and the related unintended streamwise gradients in the approach-flow profiles.

A remarkable feature in the comparison between CFD and PIV results is the differences between both sets of results in the immediate vicinity of the ventilation openings. The sensitivity study with CFD shows that this is the region where the CFD results are the least sensitive to the choice of the computational parameters. On the other hand, this is also the region where the differences with the PIV results are the largest. The most likely explanation for this, given the good agreement between CFD and PIV results at the other positions of the flow field, is the same as mentioned by Karava et al. [28]: inaccuracies in the PIV measurements due to reflections and shading effects. Note that inaccuracies in these regions can indeed spread out spatially to some extent due to the interpolation process applied to the PIV results.

\section{Summary and conclusions}

Accurate CFD simulations of coupled outdoor wind flow and indoor air flow are essential for the design and evaluation of natural cross-ventilation strategies for buildings. It is widely recognized that CFD simulations can be very sensitive to the large number of computational parameters that have to be set by the user. Therefore, detailed and generic sensitivity analyses of the impact of these parameters on the simulation results are important to provide guidance for the execution and evaluation of future CFD studies. A detailed review of the literature indicates that there is a lack of extensive generic sensitivity studies for CFD simulation of natural cross-ventilation. In order to provide such a study, this paper has presented a series of coupled 3D steady RANS simulations for a generic isolated building. The CFD simulations are validated based on detailed wind tunnel experiments with Particle Image Velocimetry (PIV). The impact of a wide range of computational parameters is investigated, including the size of the computational domain, the resolution of the computational grid, the inlet turbulent kinetic energy profile of the atmospheric boundary layer, the turbulence model, the order of the discretization schemes and the iterative convergence criteria.

First, a reference case was defined, whose results in terms of mean air speed showed a very close agreement with detailed PIV measurements. This reference case had a computational domain with cross-section with width $\mathrm{W}_{\mathrm{D}}=\mathrm{W}+10 \mathrm{H}$ and height $\mathrm{H}_{\mathrm{D}}=\mathrm{H}+5 \mathrm{H}$, according to the existing CFD best practice guidelines. For the present configuration, it was shown that these guidelines are sufficient to provide results that are independent of the cross-sectional domain size. The computational grid with 575,247 showed sufficient grid convergence and sufficiently accurate results. The impact of the inlet turbulent kinetic energy profile was very large. This is an important result, because, to the best of our knowledge, this large impact has not been shown before. This is particularly important because there is no consensus in literature on how the inlet turbulent kinetic energy profile should be calculated from the profiles of mean wind speed and streamwise turbulence intensity. Many simulations in this study showed oscillatory convergence. This behavior was attributed to the fact that the flow is intrinsically unsteady, but is forced into a steady solution by the application of the steady RANS approach. This means that special care should be applied when extracting results from steady RANS results of intrinsically unsteady flow phenomena. It was shown that the effect of turbulent kinetic energy is increased mixing of momentum, which also smoothens out the instabilities. In terms of turbulence model, the best performance was 
shown by the SST k- $\omega$ model, followed by the RNG k- $\varepsilon$ model. The other models were insufficiently capable of reproducing the magnitude and position of the standing vortex upstream of the building facade, and of the resulting direction of the jet through the ventilation opening. This study has shown the strong impact of the prediction accuracy of the outdoor standing vortex on the prediction accuracy of the indoor ventilation flow. Finally, the importance of at least second-order accurate discretization schemes was confirmed, as well as sufficiently stringent convergence criteria. It is stressed that the convergence criteria suggested by commercial CFD codes are often too lenient and not stringent enough for accurate simulation results.

Future work should focus on extending this type of detailed and systematic sensitivity analysis to other building geometries, including different positions and sizes of ventilation openings, and to other parameters including upstream aerodynamic roughness length and indoor turbulence intensities and turbulent diffusivities. In spite of the very large amount of very valuable CFD cross-ventilation studies performed in the past, this topic still requires further investigation, in particular concerning sensitivity analysis.

\section{Acknowledgements}

The authors are very grateful to their colleagues who have provided very valuable experimental data that have supported our research work, in particular Dr. Panagiota Karava, Dr. Andreas Athienitis and Dr. Ted Stathopoulos. The CFD simulations in this paper have benefited from the hard-ware support by the Laboratory of the Unit Building Physics and Systems at Eindhoven University of Technology, headed by Ing. Jan Diepens.

\section{References}

[1] Finnegan MJ, Pickering CA, Burge PS. The sick building syndrome: prevalence studies. Br Med J (Clin Res Ed) 1984;289:1573-5.

[2] Carrilho da Graça G, Chen Q, Glicksman LR, Norford LK. Simulation of wind-driven ventilative cooling systems for an apartment building in Beijing and Shanghai. Energy Build 2002;34:1-11.

[3] Chang WR. Effect of porous hedge on cross ventilation of a residential building. Build Environ 2006;41:54956.

[4] Chen Q, Glicksman LR, Lin J, Scott A. Sustainable urban housing in China. J Harbin Inst Tech (New Series) 2007; 14:6-9.

[5] Chen Q. Ventilation performance prediction for buildings: A method overview and recent applications. Build Environ 2009;44:848-58.

[6] Tablada A, De Troyer F, Blocken B, Carmeliet J, Verschure H. On natural ventilation and thermal comfort in compact urban environments-the Old Havana case. Build Environ 2009;44:1943-58.

[7] Heiselberg P, Perino M. Short-term airing by natural ventilation-implication on IAQ and thermal comfort. Indoor Air 2010;20:126-40.

[8] van Hooff T, Blocken B. Coupled urban wind flow and indoor natural ventilation modelling on a highresolution grid: A case study for the Amsterdam ArenA stadium. Environ Modell Softw 2010;25:51-65.

[9] Linden PF. The fluid mechanics of natural ventilation. Annu Rev Fluid Mech 1999;31:201-38.

[10] Hunt GR, Linden PP. The fluid mechanics of natural ventilation - displacement ventilation by buoyancydriven flows assisted by wind. Build Environ 1999;34:707-20.

[11] Li YG, Delsante A. Natural ventilation induced by combined wind and thermal forces. Build Environ 2001;36:59-71.

[12] Tan G, Glicksman LR. Application of integrating multi-zone model with CFD simulation to natural ventilation prediction. Energy Build 2005;37:1049-57.

[13] Larsen TS, Heiselberg P. Single-sided natural ventilation driven by wind pressure and temperature difference. Energy Build 2008;40:1031-40.

[14] Reichrath S, Davies TW. Using CFD to model the internal climate of greenhouses: past, present and future. Agronomie 2002;22:3-19.

[15] Karava P, Stathopoulos T, Athienitis AK. Wind driven flow through openings-a review of discharge coefficients. Int J Vent 2004;3:255-66.

[16] Karava P, Stathopoulos T, Athienitis AK. Impact of internal pressure coefficients on wind-driven ventilation analysis. Int J Vent 2006;5:53-66.

[17] Norton T, Sun DW. Computational fluid dynamics (CFD)-an effective and efficient design and analysis tool for the food industry: A review. Trends Food Sci Technol 2006;17:600-20.

[18] Norton T, Sun DW, Grant J, Fallon R, Dodd V. Applications of computational fluid dynamics (CFD) in the modelling and design of ventilation systems in the agricultural industry: A review. Bioresour Technol 2007;98:2386-414.

[19] Etheridge DW, Nolan J. Ventilation measurements at model scale in a turbulent flow. Build Environ 1979; 14:53-64. 
[20] Murakami S, Kato S, Akabayashi S, Mizutani K, Kim Y. Wind tunnel test on velocity-pressure field of cross-ventilation with open windows. ASHRAE Trans 1991;97:525-38.

[21] Kato S, Murakami S, Mochida A, Akabayashi S, Tominaga Y. Velocity-pressure field of cross ventilation with open windows analyzed by wind tunnel and numerical simulation. J Wind Eng Ind Aerodyn 1992;44:2575-86.

[22] Kato S, Murakami S, Takahashi T, Gyobu T. Chained analysis of wind tunnel test and CFD on cross ventilation of large-scale market building. J Wind Eng Ind Aerodyn 1997;67-68:573-87.

[23] Jiang Y, Alexander D, Jenkins H, Arthur R, Chen Q. Natural ventilation in buildings: measurement in a wind tunnel and numerical simulation with large-eddy simulation. J Wind Eng Ind Aerodyn 2003;91:33153.

[24] Heiselberg P, Li Y, Andersen A, Bjerre M, Chen Z. Experimental and CFD evidence of multiple solutions in a naturally ventilated building. Indoor Air 2004;14:43-54.

[25] Karava P, Stathopoulos T, Athienitis AK. Wind-induced natural ventilation analysis. Sol Energy 2007;81:20-30.

[26] Bu Z, Kato S, Takahashi T. Wind tunnel experiments on wind-induced natural ventilation rate in residential basements with areaway space. Build Environ 2010;45:2263-72.

[27] Ji L, Tan H, Kato S, Bu Z, Takahashi T. Wind tunnel investigation on influence of fluctuating wind direction on cross natural ventilation. Build Environ 2011;46:2490-9.

[28] Karava P, Stathopoulos T, Athienitis AK. Airflow assessment in cross-ventilated buildings with operable façade elements. Build Environ 2011;46:266-79.

[29] Karava P, Stathopoulos T. Wind-induced internal pressures in buildings with large façade openings. J Eng Mech In press, DOI: 10.1061/(ASCE)EM.1943-7889.0000296.

[30] Etheridge DW, Sandberg M. A simple parametric study of ventilation. Build Environ 1984;19:163-73.

[31] Haghighat F, Rao J, Fazio P. The influence of turbulent wind on air change rates-a modelling approach. Build Environ 1991;26:95-109.

[32] Etheridge DW. Nondimensional methods for natural ventilation design. Build Environ 2002;37:1057-72.

[33] Costola D, Blocken B, Hensen JLM. Overview of pressure coefficient data in building energy simulation and airflow network programs. Build Environ 2009;44:2027-36.

[34] Costola D, Blocken B, Ohba M, Hensen J. Uncertainty in airflow rate calculations due to the use of surfaceaveraged pressure coefficients. Energy Build 2010;42:881-8.

[35] Li Y, Delsante A, Symons J. Prediction of natural ventilation in buildings with large openings. Build Environ 2000;35:191-206.

[36] Hensen JLM. Integrated building airflow simulation. In: Malkawi A, Augenbroe G, editors. Advanced Building Simulation, New York: Spon Press; 2004, p. 87-118.

[37] Hirano T, Kato S, Murakami S, Ikaga T, Shiraishi Y. A study on a porous residential building model in hot and humid regions: Part 1-the natural ventilation performance and the cooling load reduction effect of the building model. Build Environ 2006;41:21-32.

[38] Hensen JLM, Lamberts R. Building Performance Simulation for Design and Operation. London: Routledge; 2011.

[39] Etheridge DW, Sandberg M. Building ventilation: theory and measurement. Chichester, New York: John Wiley \& Sons; 1996.

[40] Awbi HB. Ventilation of buildings. London: New York: Spon Press; 2003.

[41] Evola G, Popov V. Computational analysis of wind driven natural ventilation in buildings. Energy Build 2006;38:491-501.

[42] van Hooff T, Blocken B. On the effect of wind direction and urban surroundings on natural ventilation of a large semi-enclosed stadium. Comput Fluids 2010;39:1146-55.

[43] Norton T, Grant J, Fallon R, Sun DW. Optimising the ventilation configuration of naturally ventilated livestock buildings for improved indoor environmental homogeneity. Build Environ 2010;45:983-95.

[44] van Hooff T, Blocken B, Aanen L, Bronsema B. A venturi-shaped roof for wind-induced natural ventilation of buildings: Wind tunnel and CFD evaluation of different design configurations. Build Environ 2011;46:1797-807.

[45] Blocken B, van Hooff T, Aanen L, Bronsema B. Computational analysis of the performance of a venturishaped roof for natural ventilation: Venturi-effect versus wind-blocking effect. Comput Fluids 2011;46:202-13.

[46] Blocken B, Stathopoulos T, Carmeliet J, Hensen JLM. Application of computational fluid dynamics in building performance simulation for the outdoor environment: an overview. J Building Perform Simul 2011;4:157-84.

[47] Horan JM, Finn DP. Sensitivity of air change rates in a naturally ventilated atrium space subject to variations in external wind speed and direction. Energy Build 2008;40:1577-85. 
[48] Jiang Y, Chen Q. Effect of fluctuating wind direction on cross natural ventilation in buildings from large eddy simulation. Build Environ 2002;37:379-86.

[49] Mistriotis A, Arcidiacono C, Picuno P, Bot GPA, Scarascia-Mugnozza G. Computational analysis of ventilation in greenhouses at zero-and low-wind-speeds. Agric For Meteorol 1997;88:121-35.

[50] Mistriotis A, Bot G, Picuno P, Scarascia-Mugnozza G. Analysis of the efficiency of greenhouse ventilation using computational fluid dynamics. Agric For Meteorol 1997;85:217-28.

[51] Straw MP, Baker CJ, Robertson AP. Experimental measurements and computations of the wind-induced ventilation of a cubic structure. J Wind Eng Ind Aerodyn 2000;88:213-30.

[52] Kurabuchi T, Ohba M, Arashiguchi A, Iwabuchi T. Numerical study of airflow structure of a cross ventilated model building. In: Air Distribution in Rooms: Ventilation for Health and Sustainable Environment 2000:313-8.

[53] Bartzanas T, Boulard T, Kittas C. Numerical simulation of the airflow and temperature distribution in a tunnel greenhouse equipped with insect-proof screen in the openings. Comput Electron Agric 2002;34:20721.

[54] Mistriotis A, Briassoulis D. Numerical estimation of the internal and external aerodynamic coefficients of a tunnel greenhouse structure with openings. Comput Electron Agric 2002;34:191-205.

[55] Shklyar A, Arbel A. Numerical model of the three-dimensional isothermal flow patterns and mass fluxes in a pitched-roof greenhouse. J Wind Eng Ind Aerodyn 2004;92:1039-59.

[56] Bartzanas T, Boulard T, Kittas C. Effect of vent arrangement on windward ventilation of a tunnel greenhouse. Biosystems Eng 2004;88:479-90.

[57] Hu CH, Kurabuchi T, Ohba M. Numerical study of cross-ventilation using two-equation RANS turbulence models. Int J Vent 2005;4:123-32.

[58] Lee I, Lee S, Kim G, Sung J, Sung S, Yoon Y. PIV verification of greenhouse ventilation air flows to evaluate CFD accuracy. Trans ASAE (Am Soc Agric Eng) 2005;48:2277-88.

[59] Mochida A, Yoshino H, Takeda T, Kakegawa T, Miyauchi S. Methods for controlling airflow in and around a building under cross-ventilation to improve indoor thermal comfort. J Wind Eng Ind Aerodyn 2005;93:437-49.

[60] Mochida A, Yoshino H, Miyauchi S, Mitamura T. Total analysis of cooling effects of cross-ventilation affected by microclimate around a building. Sol Energy 2006;80:371-82.

[61] Fatnassi H, Boulard T, Poncet C, Chave M. Optimisation of greenhouse insect screening with computational fluid dynamics. Biosystems Eng 2006;93:301-12.

[62] Wright NG, Hargreaves DM. Unsteady CFD Simulations for natural ventilation. Int J Vent 2006;5:13-20.

[63] Asfour OS, Gadi MB. A comparison between CFD and Network models for predicting wind-driven ventilation in buildings. Build Environ 2007;42:4079-85.

[64] Bartzanas T, Kittas C, Sapounas AA, Nikita-Martzopoulou C. Analysis of airflow through experimental rural buildings: Sensitivity to turbulence models. Biosystems Eng 2007;97:229-39.

[65] Stavrakakis GM, Koukou MK, Vrachopoulos MG, Markatos NC. Natural cross-ventilation in buildings: Building-scale experiments, numerical simulation and thermal comfort evaluation. Energy Build 2008;40:1666-81.

[66] Teitel M, Ziskind G, Liran O, Dubovsky V, Letan R. Effect of wind direction on greenhouse ventilation rate, airflow patterns and temperature distributions. Biosystems Eng 2008;101:351-69.

[67] Wang L, Wong NH. Coupled simulations for naturally ventilated residential buildings. Autom Constr 2008; 17:386-98.

[68] Hu CH, Ohba M, Yoshie R. CFD modelling of unsteady cross ventilation flows using LES. J Wind Eng Ind Aerodyn 2008;96:1692-706.

[69] Wang L, Wong NH. Coupled simulations for naturally ventilated rooms between building simulation (BS) and computational fluid dynamics (CFD) for better prediction of indoor thermal environment. Build Environ 2009;44:95-112.

[70] Norton T, Grant J, Fallon R, Sun DW. Assessing the ventilation effectiveness of naturally ventilated livestock buildings under wind dominated conditions using computational fluid dynamics. Biosystems Eng 2009;103:78-99.

[71] Kobayashi T, Sagara K, Yamanaka T, Kotani H, Takeda S, Sandberg M. Stream tube based analysis of problems in prediction of cross-ventilation rate. Int J Vent 2009;7:321-34.

[72] Meroney RN. CFD prediction of airflow in buildings for natural ventilation. Proceedings 11th Americas Conference on Wind Engineering, San Juan, Puerto Rico 2009:1-11.

[73] Kobayashi T, Sandberg M, Kotani H, Claesson L. Experimental investigation and cfd analysis of crossventilated flow through single room detached house model. Build Environ 2010;45:2723-34.

[74] Norton T, Grant J, Fallon R, Sun DW. Improving the representation of thermal boundary conditions of livestock during CFD modelling of the indoor environment. Comput Electron Agric 2010;73:17-36. 
[75] Nikas KS, Nikolopoulos N, Nikolopoulos A. Numerical study of a naturally cross-ventilated building. Energy Build 2010;42:422-34.

[76] Wu YC, Yang AS, Tseng LY, Liu CL. Myth of ecological architecture designs: comparison between design concept and computational analysis results of natural-ventilation for tjibaou cultural center in new caledonia. Energy Build 2011;43:2788-97.

[77] Larsen TS, Nikolopoulos N, Nikolopoulos A, Strotos G, Nikas KS. Characterization and prediction of the volume flow rate aerating a cross ventilated building by means of experimental techniques and numerical approaches. Energy Build 2011;43:1371-81.

[78] Cheung JOP, Liu CH. CFD simulations of natural ventilation behaviour in high-rise buildings in regular and staggered arrangements at various spacings. Energy Build 2011;43:1149-58.

[79] Jones W, Launder B. The prediction of laminarization with a two-equation model of turbulence. Int J Heat Mass Transfer 1972;15:301-14.

[80] Yakhot V, Orszag SA, Thangam S, Gatski TB, Speziale CG. Development of turbulence models for shear flows by a double expansion technique. Phys Fluids 1992;4:1510-20.

[81] Choudhury D. Introduction to the renormalization group method and turbulence modeling. 1993;Technical Memorandum TM-107.

[82] Shih TH, Liou WW, Shabbir A, Yang Z, Zhu J. A new k- $\varepsilon$ eddy viscosity model for high Reynolds number turbulent flows. Comput Fluids 1995;24:227-38.

[83] Chen YS, Kim SW. Computation of turbulent flows using an extended k- $\varepsilon$ turbulence closure model. NASA STI/Recon Technical Report N 1987;88:11969.

[84] Kato M, Launder BE. The modeling of turbulent flow around stationary and vibrating square cylinders. 9th Symposium on Turbulent Shear Flows, Tokyo 1993; 1041-46.

[85] Tsuchiya M, Murakami S, Mochida A, Kondo K, Ishida Y. Development of a new k- $\varepsilon$ model for flow and pressure fields around bluff body. J Wind Eng Ind Aerodyn 1997;67:169-82.

[86] Durbin P. On the k- $\varepsilon$ stagnation point anomaly. Int J Heat Fluid Flow 1996;17:89-90.

[87] Wilcox DC. Turbulence modeling for CFD. La Canada, California: DCW Industries, Inc., 1998.

[88] Menter FR. Two-equation eddy-viscosity turbulence models for engineering applications. AIAA J 1994;32:1598-605.

[89] Launder BE, Reece GJ, Rodi W. Progress in the development of a Reynolds-stress turbulence closure. J Fluid Mech 1975;68:537-66.

[90] Smagorinsky J. General circulation experiments with the primitive equations. Mon Weather Rev 1963;91:99-164.

[91] Spalart PR, Jou WH, Strelets M, Allmaras SR. Comments on the Feasibility of LES for Wings and on the Hybrid RANS/LES Approach. Advances in DNS/LES, Proceedings of the First AFOSR International Conference on DNS/LES 1997.

[92] Seifert J, Li Y, Axley J, Rösler M. Calculation of wind-driven cross ventilation in buildings with large openings. J Wind Eng Ind Aerodyn 2006;94:925-47.

[93] Sandberg M. An alternative view on the theory of cross-ventilation. Int J Vent 2004;4:409-18.

[94] Richards PJ, Hoxey RP. Appropriate boundary conditions for computational wind engineering models using the k- $\varepsilon$ turbulence model. J Wind Eng Ind Aerodyn 1993;46-47:145-53.

[95] Casey M, Wintergerste T. ERCOFTAC special interest group on quality and trust in industrial CFD: best practices guidelines. European Research Community on Flow, Turbulence and Combustion 2000.

[96] Franke J, Hellsten A, Schlünzen H, Carissimo B. Best practice guideline for the CFD simulation of flows in the urban environment. 2007.

[97] Blocken B, Stathopoulos T, Carmeliet J. CFD simulation of the atmospheric boundary layer: wall function problems. Atmos Environ 2007;41:238-52.

[98] Tominaga Y, Mochida A, Yoshie R, Kataoka H, Nozu T, Yoshikawa M et al. AIJ guidelines for practical applications of CFD to pedestrian wind environment around buildings. J Wind Eng Ind Aerodyn 2008;96:1749-61.

[99] Chen Q, Srebric J. How to verify, validate, and report indoor environment modeling CFD analysis, ASHRAE RP-1133. Atlanta, GA: ASHRAE 2001.

[100] Stathopoulos T. Design and fabrication of a wind tunnel for building aerodynamics. J Wind Eng Ind Aerodyn 1984;16:361-76.

[101] Karava P. Airflow prediction in buildings for natural ventilation design: Wind tunnel measurements and simulation. Ph.D.Thesis; Department of Building, Civil and Environmental Engineering, Concordia University, Montreal Quebec 2008.

[102] Blocken B, Stathopoulos T, Carmeliet J. Wind environmental conditions in passages between two long narrow perpendicular buildings. J Aerospace Eng - ASCE 2008;21:280-7.

[103] Blocken B, Moonen P, Stathopoulos T, Carmeliet J. Numerical Study on the Existence of the Venturi Effect in Passages between Perpendicular Buildings. J Eng Mech - ASCE 2008;134:1021-8. 
[104] Blocken B, Carmeliet J, Stathopoulos T. CFD evaluation of wind speed conditions in passages between parallel buildings-effect of wall-function roughness modifications for the atmospheric boundary layer flow. J Wind Eng Ind Aerodyn 2007;95:941-62.

[105] Launder BE, Spalding DB. The numerical computation of turbulent flows. Comput Methods Appl Mech Eng 1974;3:269-89.

[106] Cebeci T, Bradshaw P. Momentum transfer in boundary layers. New York: Hemisphere Publishing Corp, 1977.

[107] Fluent Inc. Fluent 6.3 User's Guide. Lebabon: Fluent Inc, 2006.

[108] Roache PJ. Perspective: a method for uniform reporting of grid refinement studies. J Fluids Eng 1994;116:405-13.

[109] Roache PJ. Quantification of uncertainty in computational fluid dynamics. Annu Rev Fluid Mech 1997;29:123-60.

[110] Freitas CJ. Journal of fluids engineering editorial policy statement on the control of numerical accuracy. ASME - J Fluids Eng 1993;115:339-40. 


\section{FIGURE CAPTIONS}

(a) Coupled approach

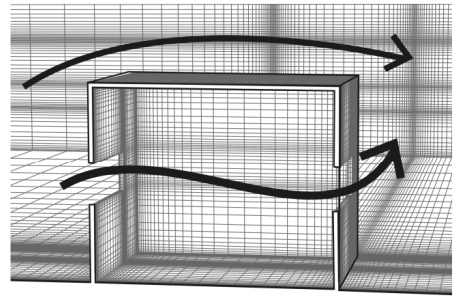

$\left[\begin{array}{c}\text { Outdoor wind flow } \\ \text { Indoor air flow }\end{array}\right]$ (b) Decoupled approach

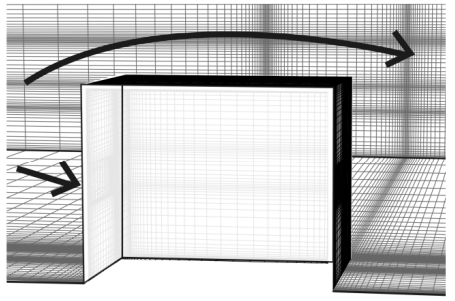

Outdoor wind flow

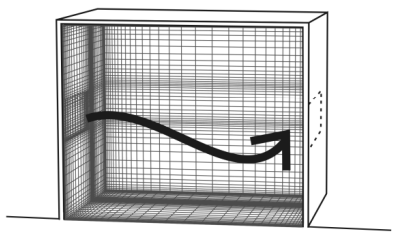

Indoor air flow

Figure 1. (a) Coupled and (b) decoupled approach for analysis of wind-induced cross-ventilation of buildings.

(a)

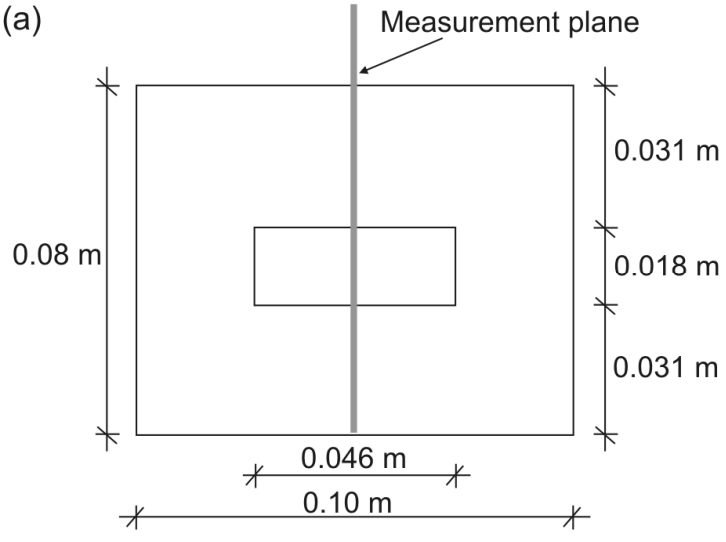

(b)

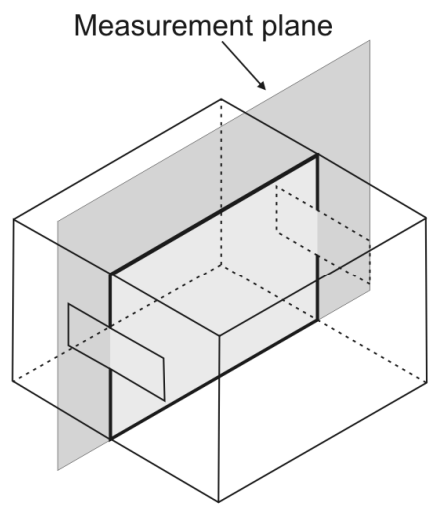

Figure 2. (a) Front view of scaled model with opening size and dimensions; (b) Measurement plane for this configuration.

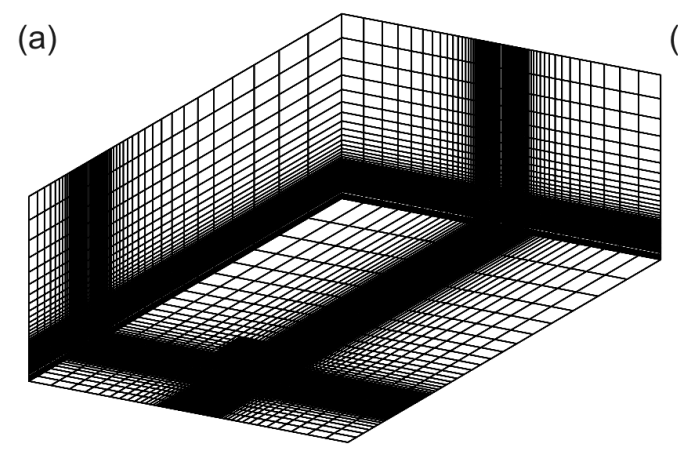

(b)

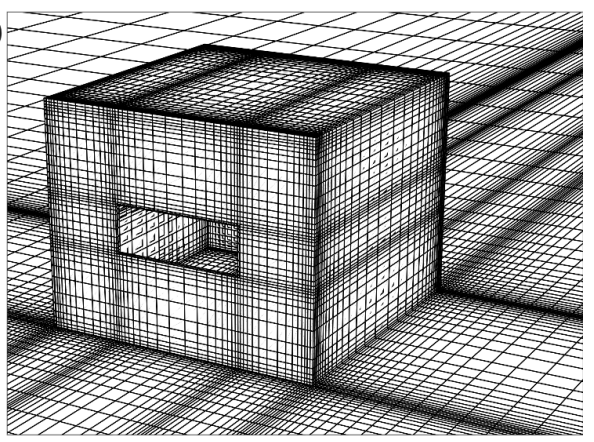

Figure 3. Computational grid (575,247 cells): (a) Perspective view of grid at bottom, side and back face of the computational domain; (b) Perspective view of grid at building surfaces and ground surface. 


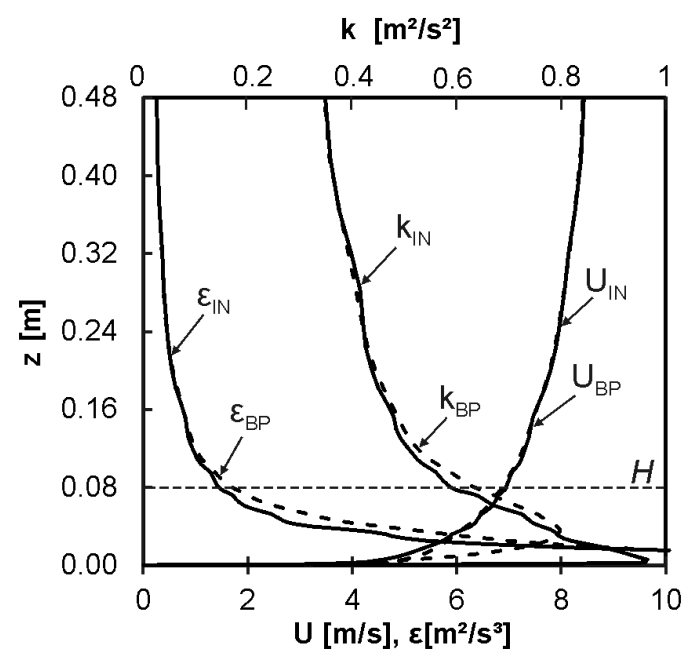

Figure 4. Profiles of the mean wind speed (U), the turbulent kinetic energy $(\mathrm{k})$ and the turbulent dissipation rate $(\varepsilon)$ at the inlet (continuous line) and at the building position (dashed line) in the empty domain. The subscripts "IN" and "BP" refer to "inlet" and "building position", respectively. The height of the model (H) is $0.08 \mathrm{~m}$ (SST k- $\omega$ model, 575,247 cells).

(a)

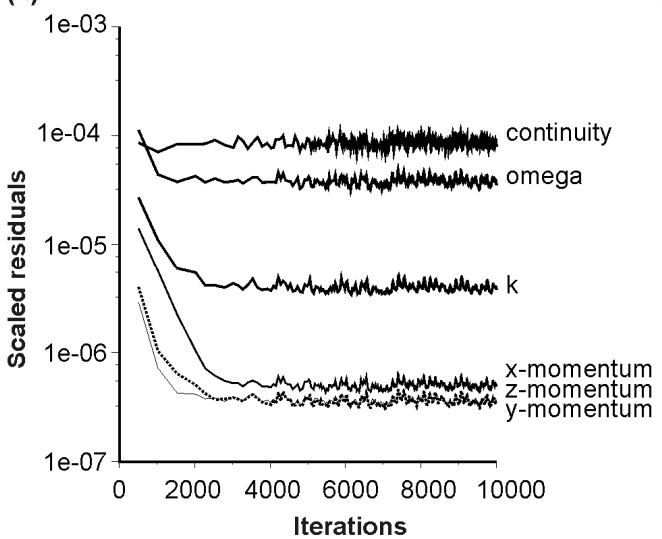

(b)

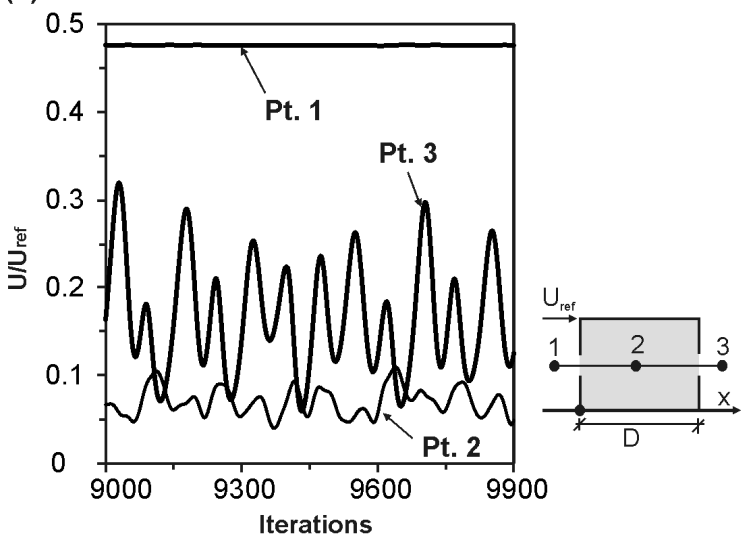

Figure 5. Convergence for the reference case: (a) Scaled residuals monitored over the first 10000 iterations; (b) Streamwise wind speed ratio monitored over 900 iterations in three selected points along the centerline: upstream $(x / D=-0.25)$ of the inlet opening (Pt.1); in the center (Pt. 2) and downstream $(x / D=1.25)$ of the outlet opening (Pt. 3). 

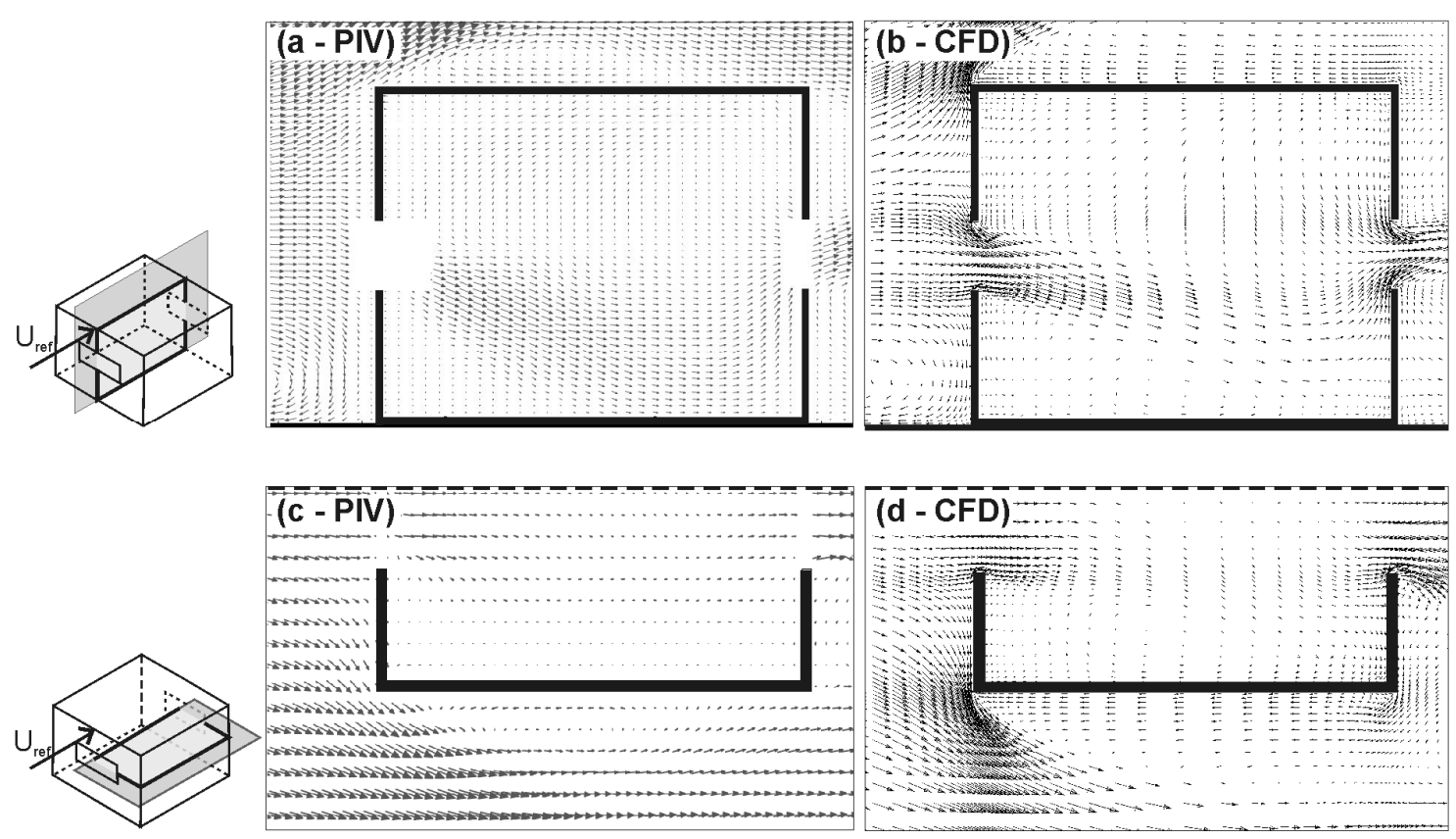

Figure 6. Comparison of the velocity vector fields obtained with the PIV measurements and the CFD simulations (reference case, SST k- $\omega$ model, 575,247 cells) in (a,b) the vertical centerplane and (c,d) the horizontal plane at mid-height through the openings. Figs. (a) and (c) are PIV data, (b) and (d) are CFD data.

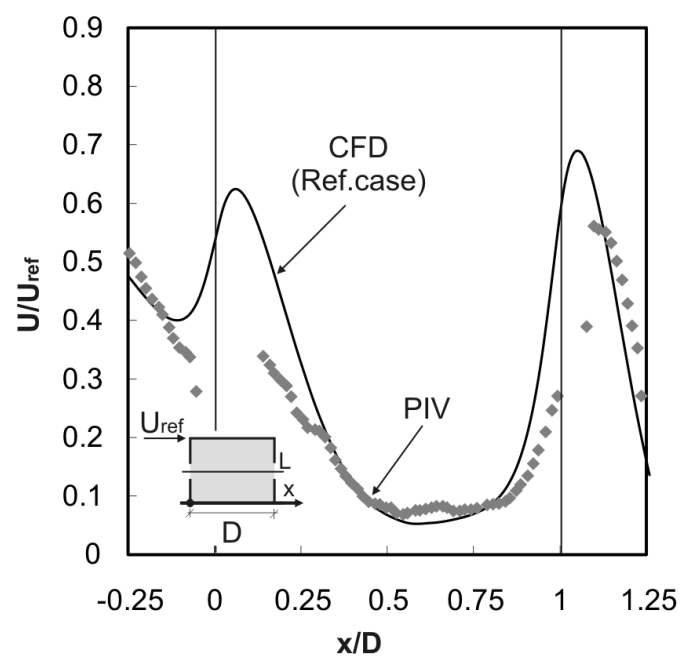

Figure 7. Comparison of experimental (PIV) and numerical results (reference case, SST k- $\omega$ model, 575,247 cells) for the streamwise wind speed ratio $\mathrm{U} / \mathrm{U}_{\mathrm{ref}}$ along the centerline. 


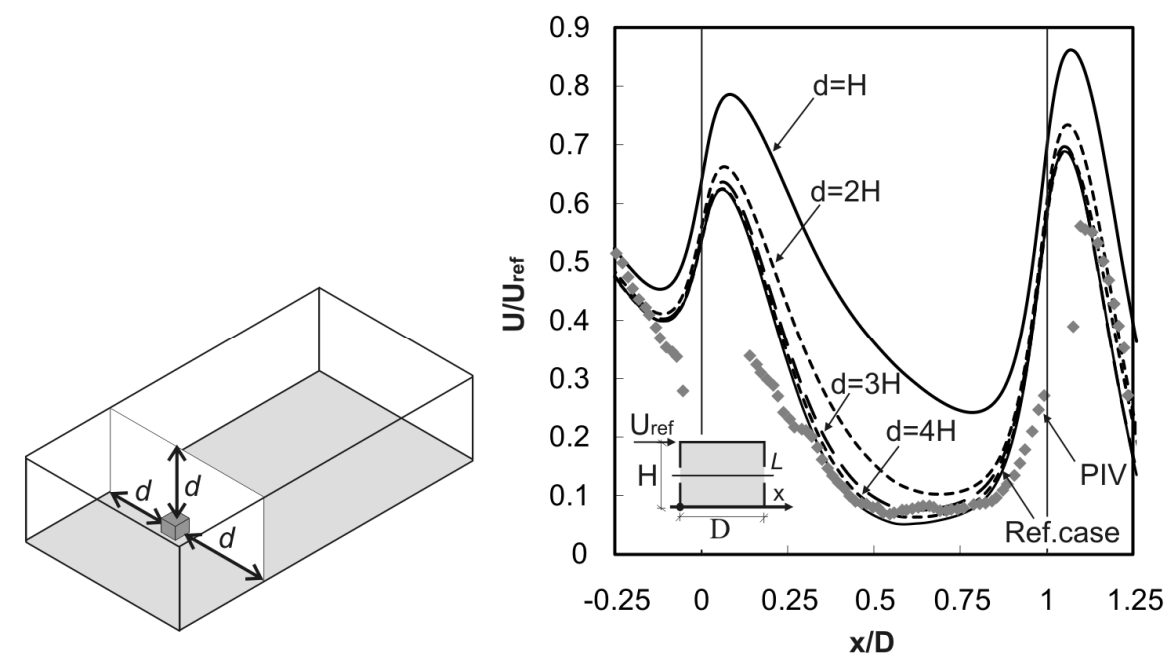

Figure 8. CFD simulation results for sensitivity analysis: impact of the size (cross-section) of the computational domain on the streamwise wind speed ratio along the centerline (SST k- $\omega$ model, 575,247 cells).

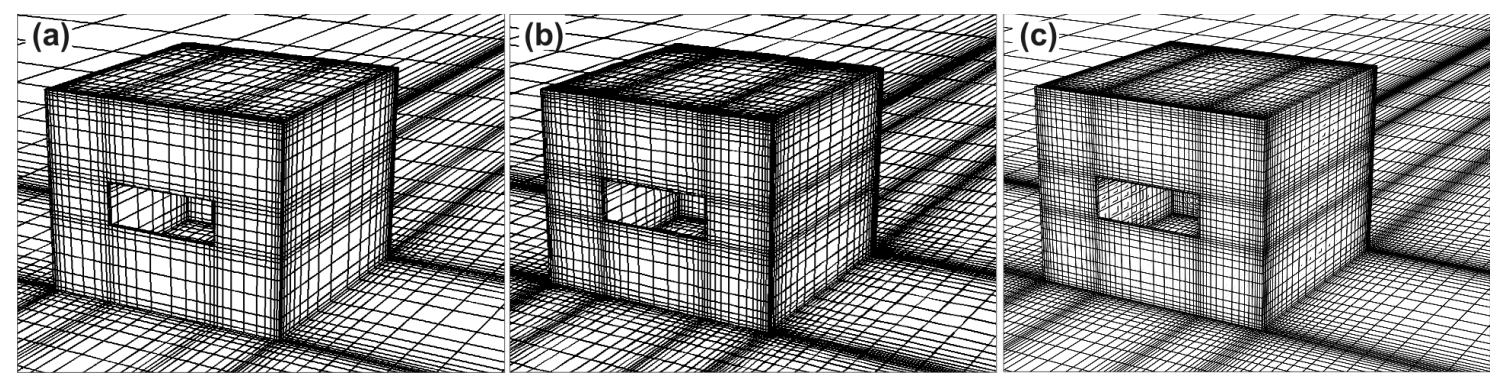

Figure 9. Perspective view of grids for grid-sensitivity analysis: (a) Coarse grid A with 144,696 cells; (b) Middle grid B with 314,080 cells; (c) Fine grid C with 575,247 cells (reference case).
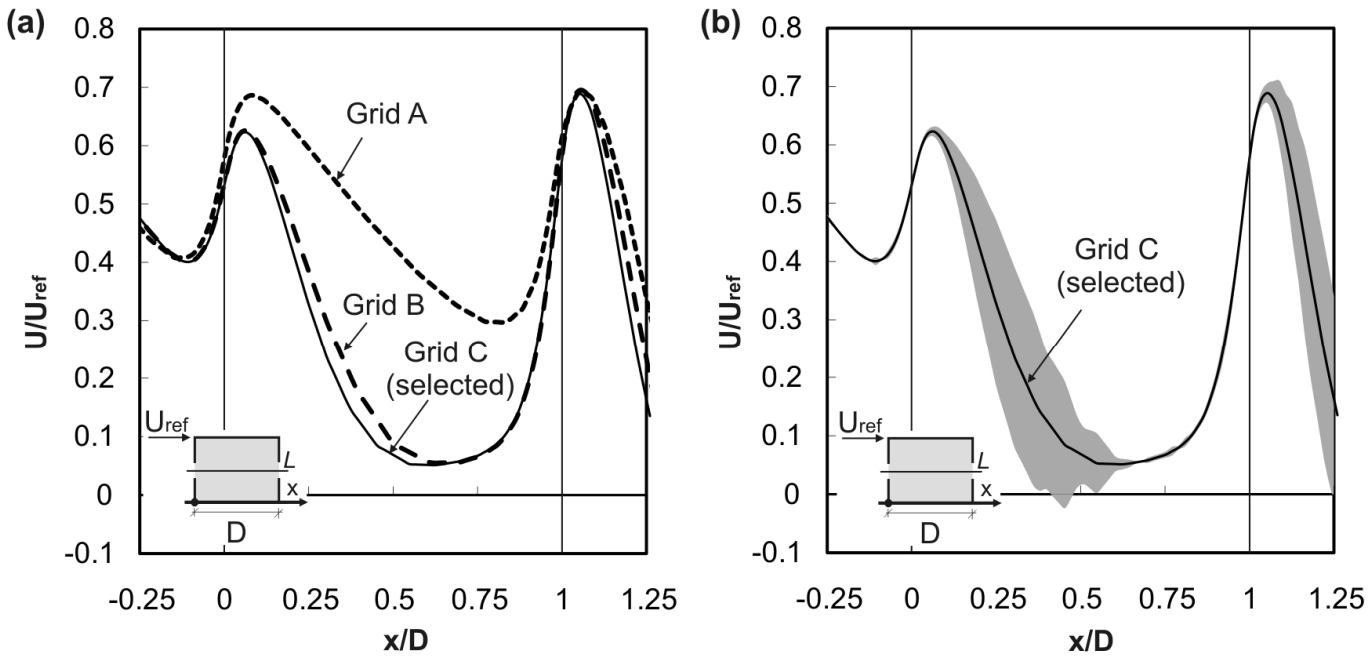

Figure 10. CFD simulation results for sensitivity analysis: impact of the grid resolution on the streamwise wind speed ratio along the centerline: (a) Comparison of results from the three grids; (b) Results on fine grid with indication of band of $1.25 \mathrm{x}$ grid-convergence index by Roache [108,109]. 

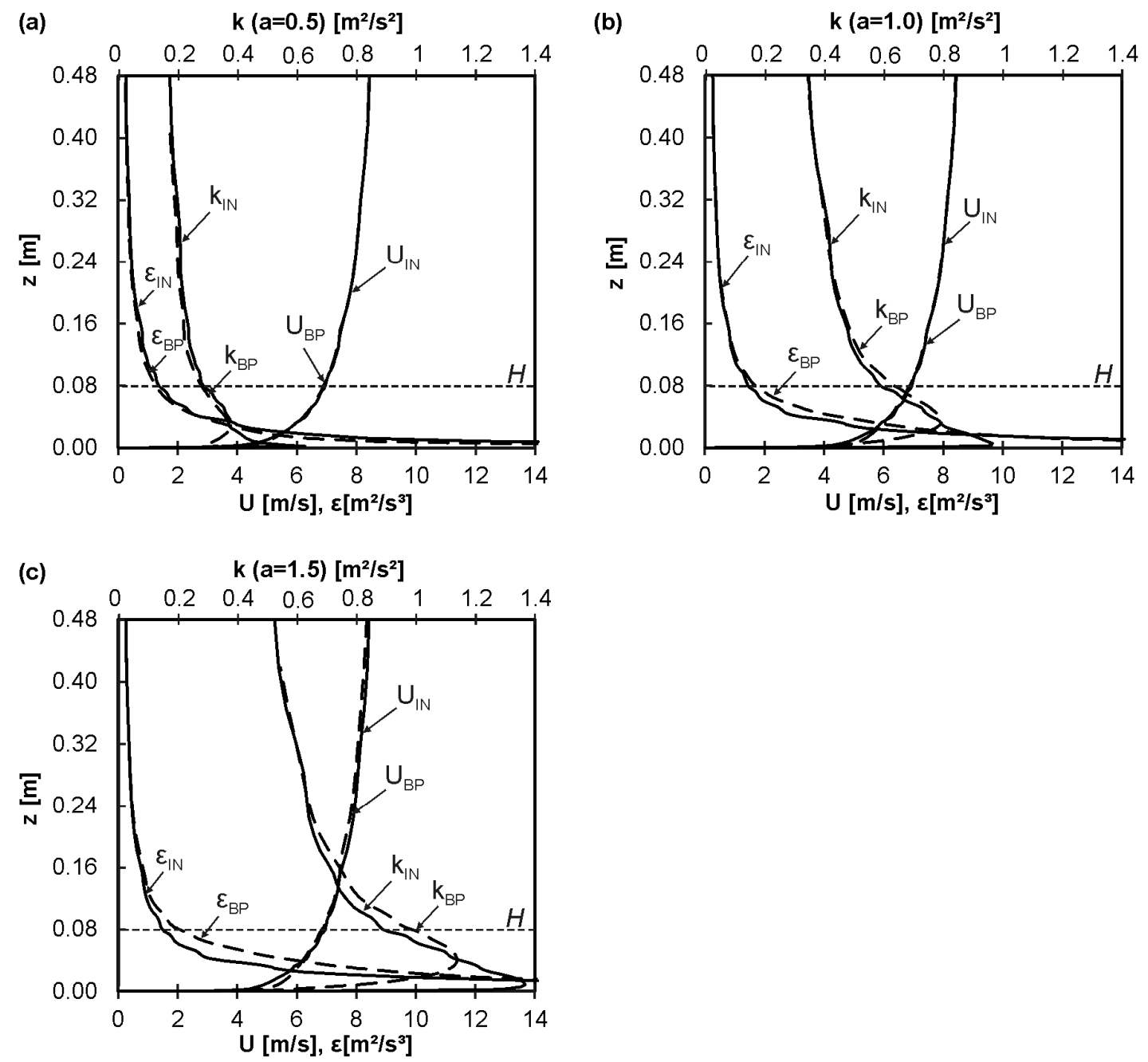

Figure 11: Influence of parameter a on horizontal homogeneity. The figures show the profiles of the mean wind speed $(\mathrm{U})$, the turbulent kinetic energy $(\mathrm{k})$ and the turbulent dissipation rate $(\varepsilon)$ at the inlet (continuous line) and at the building position (dashed line) in the empty domain. The subscripts "IN" and "BP" refer to "inlet" and "building position", respectively. The height of the model $(\mathrm{H})$ is $0.08 \mathrm{~m}$ (SST k- $\omega$ model, 575,247 cells). 


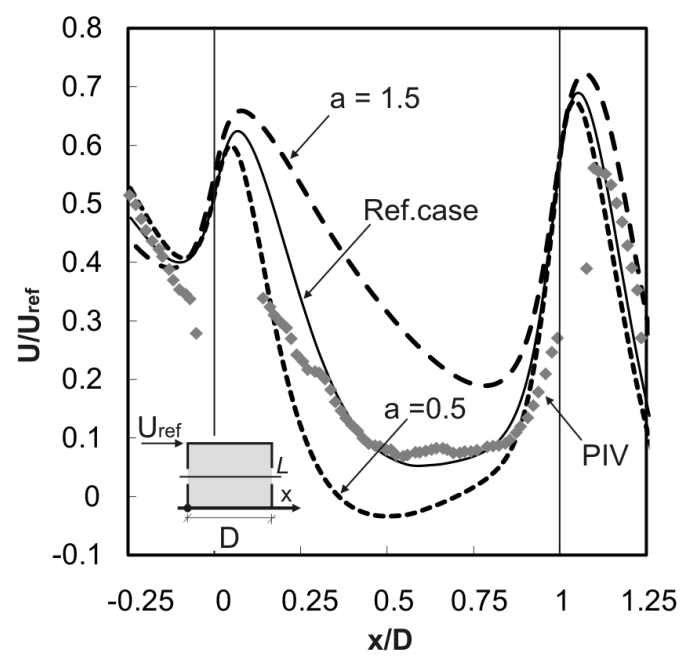

Figure 12: CFD simulation results for sensitivity analysis: impact of approach-flow turbulent kinetic energy profile parameter $a$ on the streamwise wind speed ratio along the centerline ( $\mathrm{a}=1$ for the reference case). 


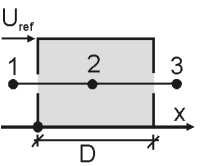

$a=1$ (Ref.case)

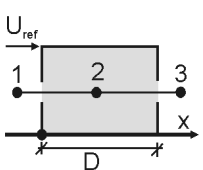

$a=1.5$

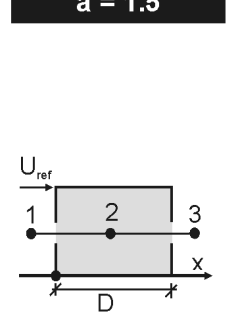

(a)

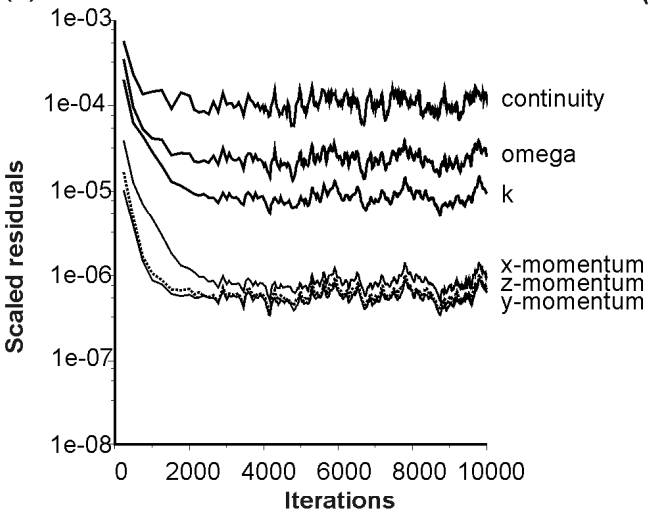

(c)

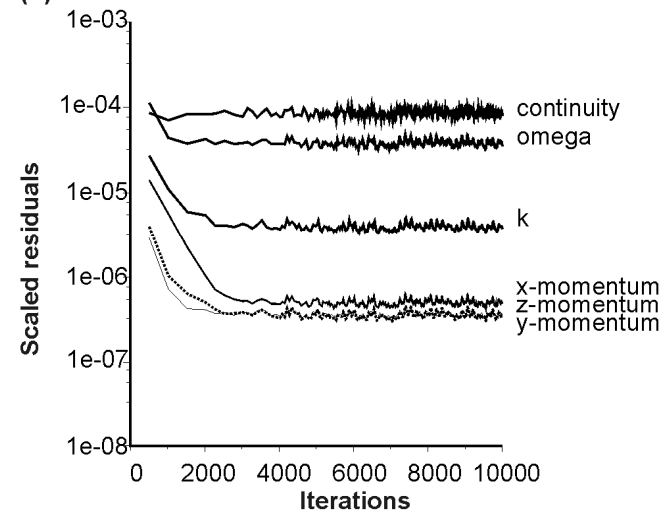

(e)

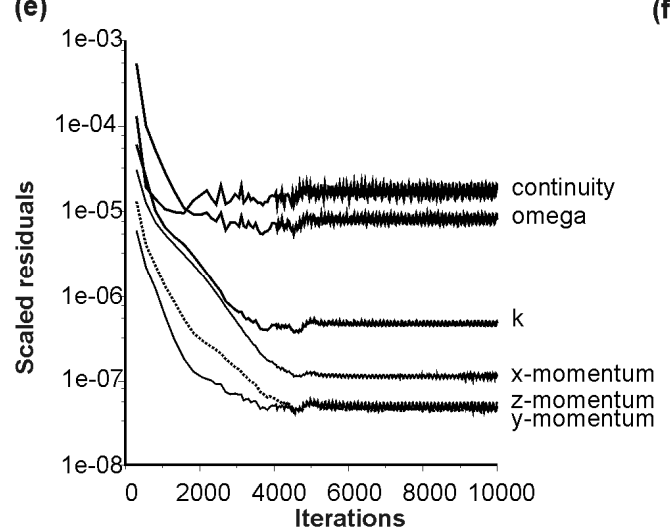

(b)

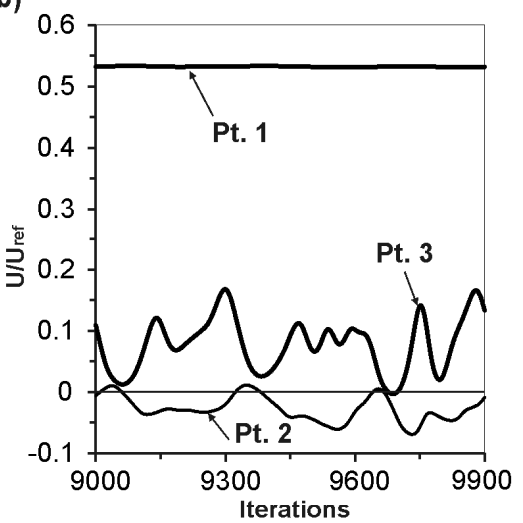

(d)

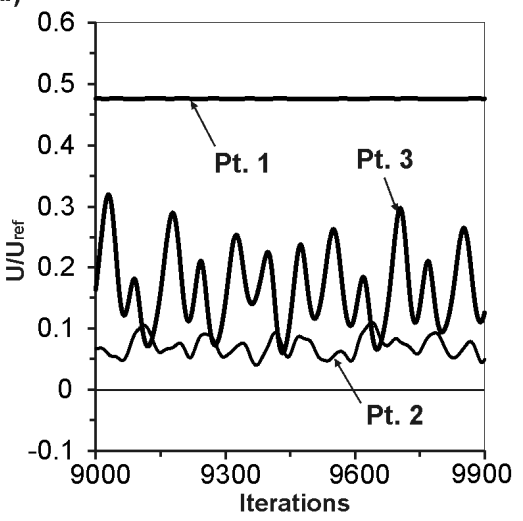

(f)

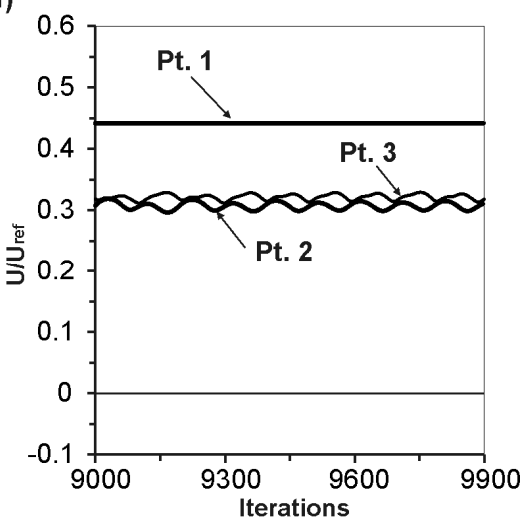

Figure 13: CFD simulation results for sensitivity analysis: impact of inlet turbulent kinetic energy profile parameter $a$ on the convergence behavior of the solution. (a,c,e) Scaled residuals monitored over the first 10000 iterations; (b,d,f) Streamwise wind speed ratio monitored over 900 iterations in three selected points along the centerline: upstream $(\mathrm{x} / \mathrm{D}=-0.25)$ of the inlet opening (Pt. 1), in the center of the model (Pt. 2) and downstream $(\mathrm{x} / \mathrm{D}=1.25)$ of the outlet opening (Pt. 3). 
(a)

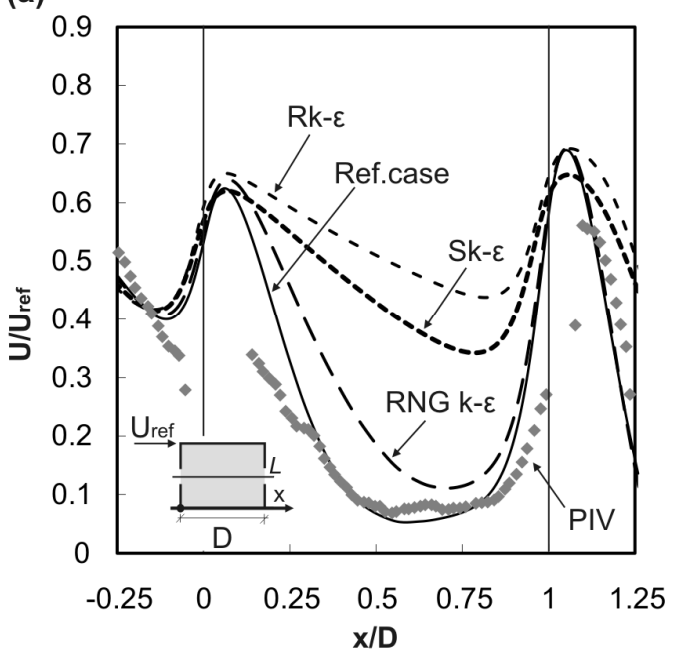

(b)

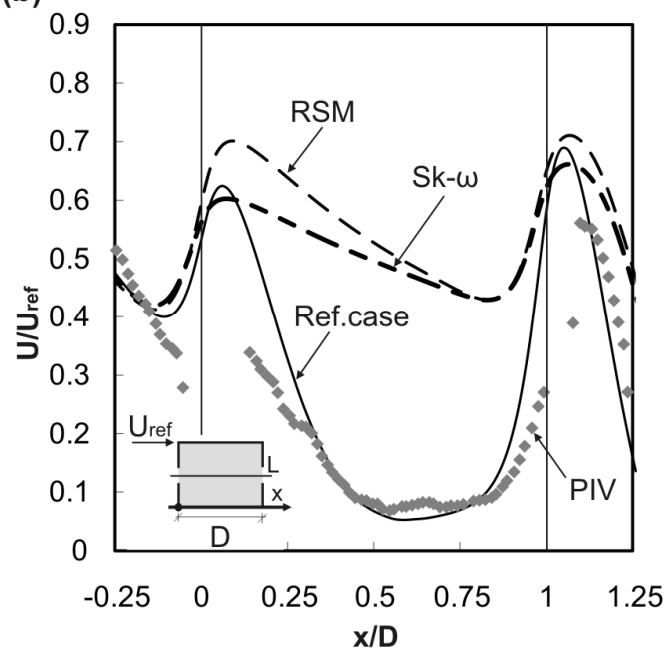

Figure 14. CFD simulation results for sensitivity analysis: impact of turbulence models on the streamwise wind speed ratio along the centerline. Comparison between the reference case (SST k- $\omega$ model) and (a) the k- $\varepsilon$ models and (b) the RSM and standard k- $\omega$ model. 

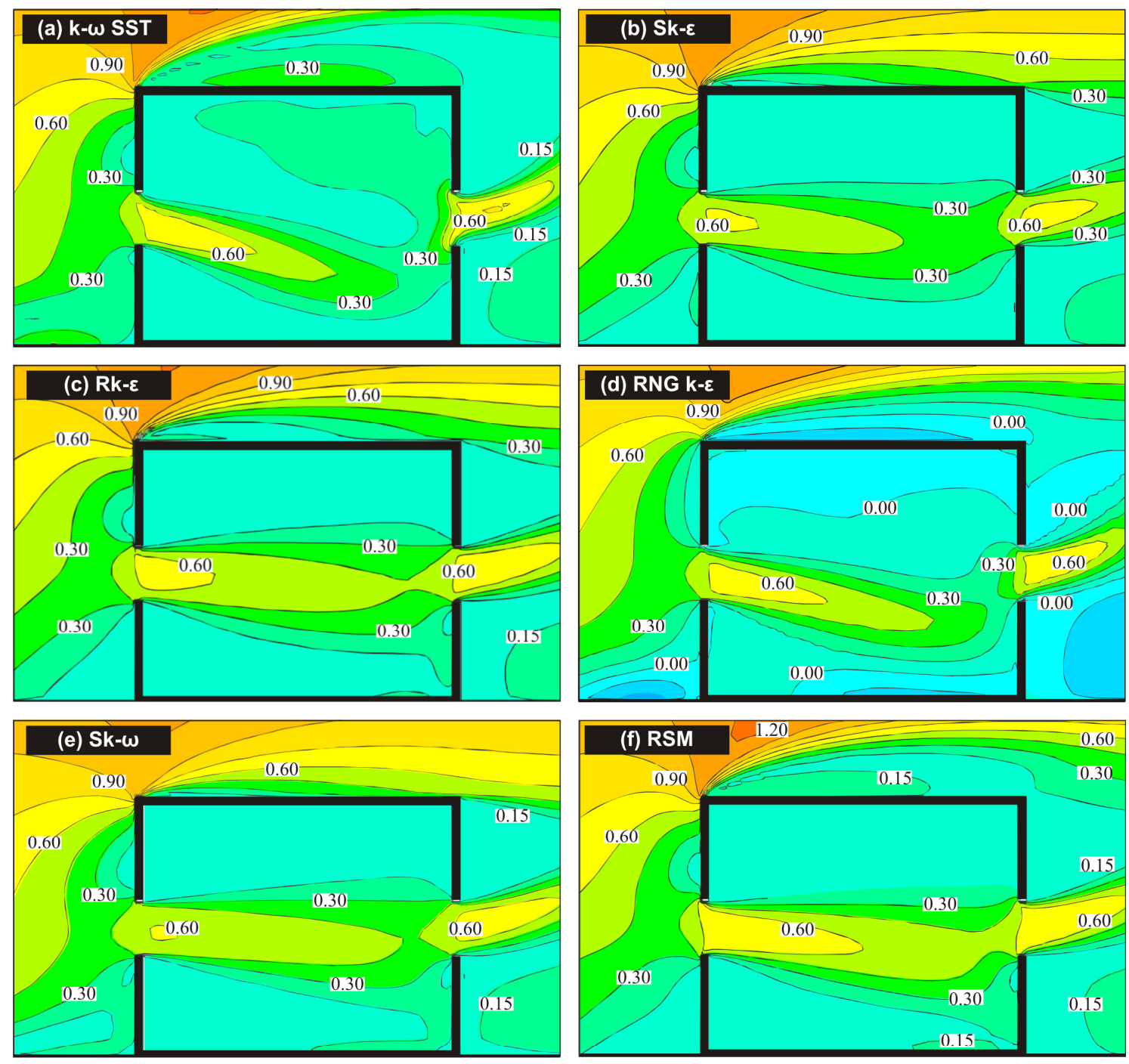

Figure 15. CFD simulation results for sensitivity analysis: impact of turbulence models on the wind speed ratio contours in the vertical centerplane. The SST k- $\omega$ model is the reference case in this study. 

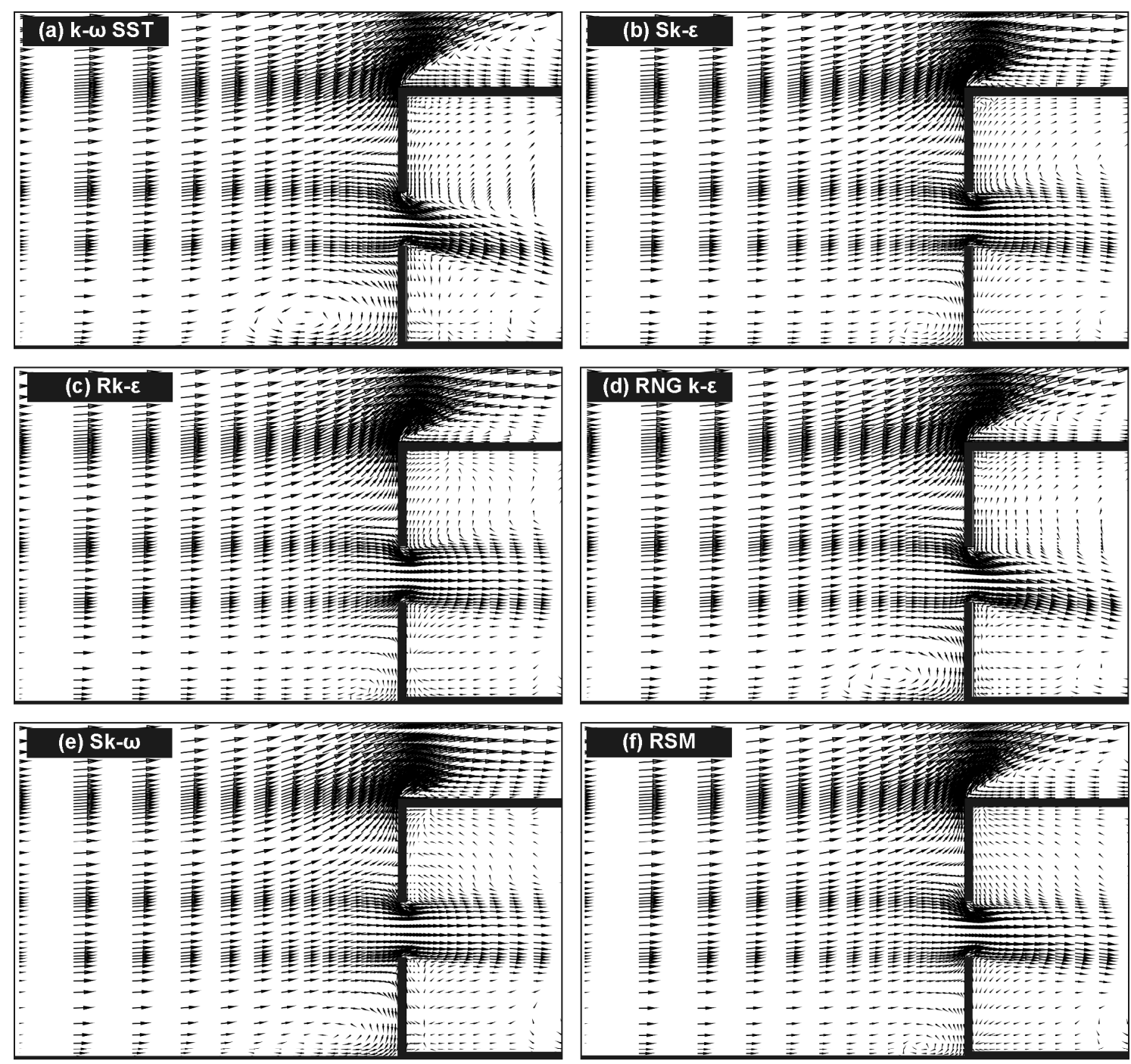

Figure 16. CFD simulation results for sensitivity analysis: impact of turbulence models on the relative velocity vector field in the vertical centerplane. The SST k- $\omega$ model is the reference case in this study. 


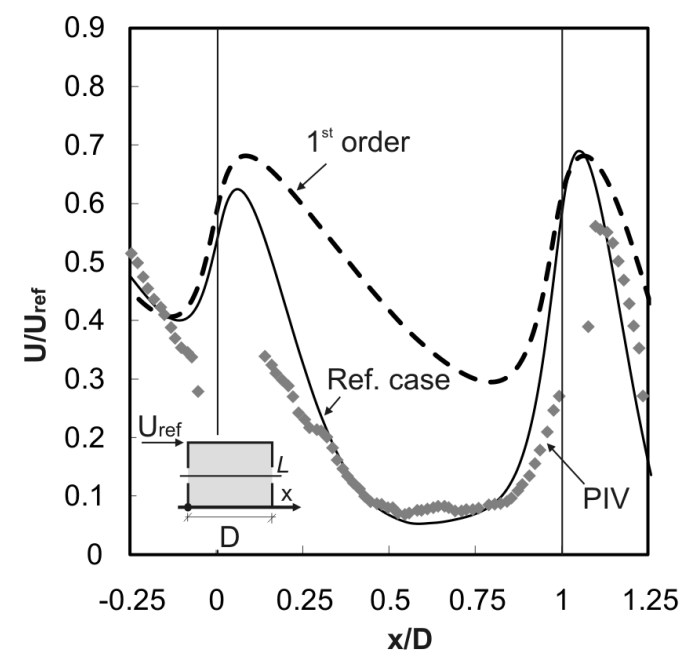

Figure 17. CFD simulation results for sensitivity analysis: impact of discretization scheme on the streamwise wind speed ratio along the centerline. For the reference case, a second-order discretization scheme is used for the both the convection terms and the viscous terms of the governing equations.

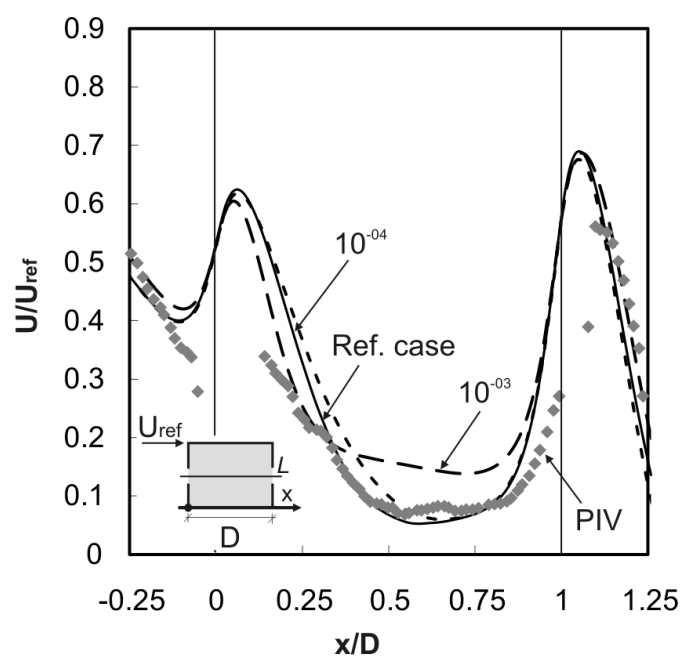

Figure 18. CFD simulation results for sensitivity analysis: impact of iterative convergence limit on the streamwise wind speed ratio along the centerline. The convergence for the reference case is assumed when all the scaled residuals leveled off and reached a minimum of $10^{-6}$ for $\mathrm{x}, \mathrm{y}$ and $\mathrm{z}$ momentum, $10^{-5}$ for $\mathrm{k}$ and $10^{-4}$ for $\omega$ and continuity (Fig. 4a). 
Table 1. Overview of wind-induced cross-ventilation studies based on coupled outdoor-indoor CFD simulations

\begin{tabular}{|c|c|c|c|c|c|c|}
\hline Authors (year) & Ref. & Study & Configuration & Turb. modeling & Validation & Sensitivity analysis \\
\hline Kato et al. (1992) & [21] & Generic & 3D / Isolated / SZ & LES (SSmag.) & $\mathrm{Y}(\mathrm{WT})$ & Buildgeom \\
\hline Mistriotis et al. (1997) & [49] & $\begin{array}{l}\text { Applied } \\
\text { Applied }\end{array}$ & $\begin{array}{l}\text { 2D/ Isolated/SZ } \\
\text { 3D/Isolated/ SZ }\end{array}$ & $\begin{array}{l}\text { RANS (SKE,CK,RNG) } \\
\text { RANS (CK) }\end{array}$ & $\begin{array}{l}\mathrm{Y}(\mathrm{WT}) \\
\mathrm{Y}(\mathrm{FS})\end{array}$ & $\begin{array}{l}\text { Turb. model } \\
\text { Buildgeom }\end{array}$ \\
\hline Mistriotis et al. (1997) & [50] & $\begin{array}{l}\text { Applied } \\
\text { Applied }\end{array}$ & $\begin{array}{l}\text { 2D/Isolated/SZ } \\
\text { 2D/ Isolated/ SZ }\end{array}$ & $\begin{array}{l}\text { RANS (RNG) } \\
\text { RANS (RNG) }\end{array}$ & $\begin{array}{l}\mathrm{Y}(\mathrm{WT}) \\
\mathrm{N}\end{array}$ & $\begin{array}{l}\text { Wsp } \\
\text { Buildgeom (openings) }\end{array}$ \\
\hline Straw et al. (2000) & [51] & Generic & 3D/ Isolated/ SZ & RANS (RNG) & $\mathrm{Y}(\mathrm{FS})$ & - \\
\hline Kurabuchi et al. (2000) & [52] & Generic & 3D/ Isolated/SZ & $\begin{array}{l}\text { RANS (SKE,LK, } \\
\text { MMK), LES (SSmag.) }\end{array}$ & $\mathrm{Y}(\mathrm{WT})$ & Turb. model \\
\hline Jiang \& Chen (2002) & {$[48]$} & Applied & 3D/ Group/ MZ & LES (SSmag.) & $\mathrm{Y}(\mathrm{WT}, \mathrm{FS})$ & Dom.size, gridres, time step \\
\hline Bartzanas et al. (2002) & [53] & Generic & 3D/Isolated/ SZ & RANS (SKE) & $\mathrm{N}$ & Screens, wdir \\
\hline $\begin{array}{l}\text { Mistriotis \& Briassoulis } \\
(2002)\end{array}$ & {$[54]$} & Generic & 2D/ Isolated/ SZ & RANS (SKE) & $\mathrm{N}$ & Buildgeom (openings), gridres \\
\hline $\begin{array}{l}\text { Carrilho da Graça et al. } \\
(2002)\end{array}$ & [2] & Applied & 3D/ Isolated/ MZ & RANS (SKE) & $\mathrm{N}$ & - \\
\hline Shklyar \& Arbel (2004) & [55] & Generic & 3D/ Isolated/ SZ & RANS (SKE) & Y (FS) & Wdir \\
\hline Bartzanas et al. (2004) & [56] & Applied & $\begin{array}{l}\text { 3D/ Isolated/ SZ } \\
\text { 2D/ Isolated/ SZ }\end{array}$ & $\begin{array}{l}\text { RANS (SKE) } \\
\text { RANS (SKE) }\end{array}$ & $\mathrm{Y}(\mathrm{FS})$ & $\begin{array}{l}\text { Gridres } \\
\text { Buildgeom (openings) }\end{array}$ \\
\hline Hu et al. (2005) & [57] & Generic & 3D/ Isolated/ SZ & $\begin{array}{l}\text { RANS (SKE,RNG, } \\
\text { SKO,SST),LES(SSmag.) }\end{array}$ & $\mathrm{Y}(\mathrm{WT})$ & Turb. model \\
\hline Tan \& Glicksman (2005) & [12] & Applied & 3D/ Isolated/ MZ & RANS (RNG) & $\mathrm{N}^{\mathrm{b}}$ & - \\
\hline Lee et al. (2005) & [58] & Generic & 3D/ Isolated/ SZ & $\begin{array}{l}\text { RANS (SKE,RNG, } \\
\text { RLZ,RSM) }\end{array}$ & $\mathrm{Y}(\mathrm{WT})$ & Gridres \\
\hline Mochida et al. $(2005,2006)$ & {$[59,60]$} & Applied & $\begin{array}{l}\text { 3D/Group \& } \\
\text { trees/SZ }\end{array}$ & RANS (DKE) & $\mathrm{Y}(\mathrm{FS})$ & $\begin{array}{l}\text { Tree arrangement, buildgeom } \\
\text { (openings) }\end{array}$ \\
\hline Evola \& Popov (2006) & [41] & Generic & 3D/ Isolated/ SZ & RANS (SKE,RNG) & $\mathrm{Y}(\mathrm{WT})$ & Gridres. \\
\hline Fatnassi et al. (2006) & [61] & Applied & 3D/ Group/ $\mathrm{SZ}^{2}$ & RANS (SKE) & $\mathrm{Y}(\mathrm{FS})$ & $\begin{array}{l}\text { Gridres, wsp, wdir, buildgeom } \\
\text { (openings) }\end{array}$ \\
\hline Chang (2006) & [3] & Generic & 3D/ Hedge $/ \mathrm{SZ}^{\mathrm{d}}$ & RANS $(\mathrm{SKE})^{\mathrm{e}}$ & $\mathrm{N}^{\mathrm{f}}$ & $\begin{array}{l}\text { Grid, hedge height, porosity } \\
\text { and position }\end{array}$ \\
\hline $\begin{array}{l}\text { Wright \& Hargreaves } \\
\text { (2006) }\end{array}$ & [62] & Generic & 30/ Isolated/ SZ & DES & & \\
\hline Asfour \& Gadi (2007) & [63] & Generic & 3D/ Isolated/ SZ & RANS (SKE) & $\mathrm{N}$ & Cell type, buildgeom, wdir \\
\hline Bartzanas et al. (2007) & [64] & Applied & 3D/ Isolated/ SZ & $\begin{array}{l}\text { RANS (SKE,RNG, } \\
\text { RLZ, RSM) }\end{array}$ & $\mathrm{Y}(\mathrm{FS})$ & Turb. model, dom.size, gridres \\
\hline
\end{tabular}




\begin{tabular}{|c|c|c|c|c|c|c|}
\hline Stravrakakis et al. (2008) & {$[65]$} & Applied & 3D/ Isolated/ SZ & RANS (SKE,RNG,RLZ) & $\mathrm{Y}(\mathrm{FS})$ & Gridres, wdir \\
\hline Horan \& Finn (2008) & [47] & Applied & 3D/ Isolated/ SZ & RANS (SKE) & $\mathrm{Y}(\mathrm{FS})^{\mathrm{g}}$ & $\begin{array}{l}\begin{array}{l}\text { Dom.size, buildgeom } \\
\text { (openings), gridres, wsp, wdir }\end{array} \\
\end{array}$ \\
\hline Teitel et al. (2008) & {$[66]$} & Applied & 3D/ Group/ SZ & RANS (SKE) & $\mathrm{Y}(\mathrm{WT}, \mathrm{FS})$ & Gridres, wdir \\
\hline Wang and Wong (2008) & [67] & $\begin{array}{l}\text { Generic } \\
\text { Applied }\end{array}$ & $\begin{array}{l}\text { 3D/ Isolated/ MZ } \\
\text { 3D/ Isolated/ MZ }\end{array}$ & $\begin{array}{l}\text { RANS (SKE) } \\
\text { RANS (SKE,RKE) }\end{array}$ & $\begin{array}{l}\mathrm{N} \\
\mathrm{Y}(\mathrm{FS}) \\
\end{array}$ & $\begin{array}{l}\text { Gridres } \\
\text { Wdir } \\
\end{array}$ \\
\hline Hu et al. (2008) & {$[68]$} & Generic & 3D / Isolated / SZ & LES (SSmag.) & $\mathrm{Y}(\mathrm{WT})$ & Wdir \\
\hline Wang and Wong (2009) & [69] & Generic & 3D / Isolated / SZ & RANS (RKE) & $\mathrm{N}^{\mathrm{h}}$ & Gridres, wdir \\
\hline Norton et al. (2009) & [70] & Applied & 3D / Isolated / SZ & RANS (SKE) & $\mathrm{Y}(\mathrm{RS})^{\mathrm{i}}$ & $\begin{array}{l}\text { Buildgeom (openings), gridres, } \\
\text { wdir }\end{array}$ \\
\hline Kobayashi et al. (2009) & {$[71]$} & Generic & 3D / Isolated / SZ & RANS (RSM) & $\mathrm{Y}(\mathrm{WT})$ & Buildgeom (openings), gridres \\
\hline Meroney (2009) & {$[72]$} & Generic & 3D / Isolated / SZ & $\begin{array}{l}\text { RANS (SKE, RNG, } \\
\text { RLZ, SKO,RSM),DES, } \\
\text { LES (SSmag.) }\end{array}$ & $\mathrm{Y}(\mathrm{WT})$ & $\begin{array}{l}\text { Buildgeom (openings), gridres, } \\
\text { turb. model }\end{array}$ \\
\hline Kobayashi et al. (2010) & {$[73]$} & Generic & 3D / Isolated / SZ & RANS (RSM) & $\mathrm{Y}(\mathrm{WT})$ & Buildgeom (openings) \\
\hline $\begin{array}{l}\text { van Hooff \& Blocken } \\
(2010)\end{array}$ & {$[8]$} & Applied & 3D/ Urban/ SZ & RANS (RKE) & $\mathrm{Y}(\mathrm{FS})$ & Buildgeom (openings) \\
\hline $\begin{array}{l}\text { van Hooff \& Blocken } \\
(2010)\end{array}$ & {$[42]$} & Applied & 3D/ Urban/ SZ & RANS (RKE) & $\mathrm{Y}(\mathrm{FS})$ & Surroundings, wdir \\
\hline Norton et al. (2010) & {$[43]$} & $\begin{array}{l}\text { Generic } \\
\text { Applied }\end{array}$ & $\begin{array}{l}\text { 3D / Isolated / SZ } \\
\text { 3D / Isolated / SZ }\end{array}$ & $\begin{array}{l}\text { RANS (SKE) } \\
\text { RANS (SKE) }\end{array}$ & $\begin{array}{l}\mathrm{Y}(\mathrm{FS}) \\
\mathrm{N}^{\mathrm{j}}\end{array}$ & $\begin{array}{l}\text { Gridres } \\
\text { Buildgeom (openings) } \\
\end{array}$ \\
\hline Norton et al. (2010) & {$[74]$} & Applied & 3D / Isolated / SZ & RANS (SKE) & $\mathrm{Y}^{\mathrm{k}}$ & Meteorological conditions \\
\hline Nikas et al. (2010) & [75] & Generic & 3D / Isolated / SZ & RANS (SKO) & $\mathrm{Y}(\mathrm{FS}, \mathrm{WT})$ & Gridres, wsp, wdir \\
\hline Wu et al. (2011) & {$[76]$} & Applied & 3D / Group / SZ & RANS (SKE) & $\mathrm{N}$ & Gridres, wdir \\
\hline Larsen et al. (2011) & {$[77]$} & Generic & 3D / Isolated / SZ & RANS (SKO) & $\mathrm{Y}(\mathrm{FS}, \mathrm{WT})$ & Gridres, wsp, wdir \\
\hline Cheung \& Liu (2011) & {$[78]$} & Generic & $\begin{array}{l}\text { 3D/ Isolated/ SZ } \\
\text { 3D/ Group/ SZ }\end{array}$ & $\begin{array}{l}\text { RANS (SKE) } \\
\text { RANS (SKE) }\end{array}$ & $\begin{array}{l}\mathrm{Y}(\mathrm{WT}) \\
\mathrm{N}\end{array}$ & Building position, wdir \\
\hline
\end{tabular}

Table legend: SZ = Single zone, MZ = Multi-zone (refers to interconnected zones). Note: MZ refers to interconnected zones. For multiple single zones, label SZ

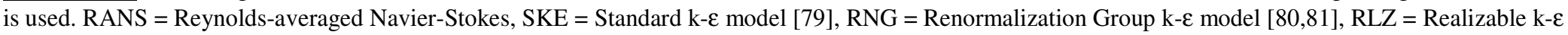
model [82],CK = Chen-Kim k- $\varepsilon$ model [83], LK = Launder-Kato k- $\varepsilon$ model [84], MMK = Murkami-Mochida-Kondo k- $\varepsilon$ model [85], DKE = Durbin k- $\varepsilon$ model [86], SKO = standard $\mathrm{k}-\omega$ model [87], SST $=$ shear-stress transport $\mathrm{k}-\omega$ model [88], RSM $=$ Reynolds stress model [89], LES = Large Eddy Simulation, $\mathrm{SSmag}$. = standard Smagorinsky subgrid-scale model [90], DES $=$ Detached Eddy Simulation [91]. Y = yes, N = no, FS $=$ full scale, RS $=$ reduced scale, WT $=$ wind tunnel. Buildgeom $=$ building geometry, dom.size $=$ domain size, gridres $=$ grid resolution, $w s p=$ wind speed, wdir $=$ wind direction .

$\left({ }^{\mathrm{a}}\right) 2$ zones in this study; $\left({ }^{\mathrm{b}}\right)$ Intention of study is comparison with multi-zone network model program; $\left({ }^{(}\right)$Porous hedge upstream of building; $\left({ }^{\mathrm{d}}\right)$ Building with two single (not interconnected) zones; (e) No atmospheric boundary layer approach flow, but uniform velocity and low (0.5\%) turbulence intensity, therefore not comparable to other studies; $\left({ }^{\mathrm{f}}\right)$ No extensive validation, brief comparison with previous work; $\left({ }^{\mathrm{g}}\right)$ Validation study not reported in this paper; $\left({ }^{\mathrm{h}}\right)$ Intention of study is validation of integrated CFD-multi-zone network model; $\left({ }^{i}\right)$ Reduced-scale (1/2) outdoor testing; ${ }^{(j)}$ ) Based on validation for generic study; $\left({ }^{k}\right)$ Validation for sub-configurations, but not for coupled CFD cross-ventilation study. 
Table 2. Overview of computational parameters for sensitivity analysis with indication of the reference case.

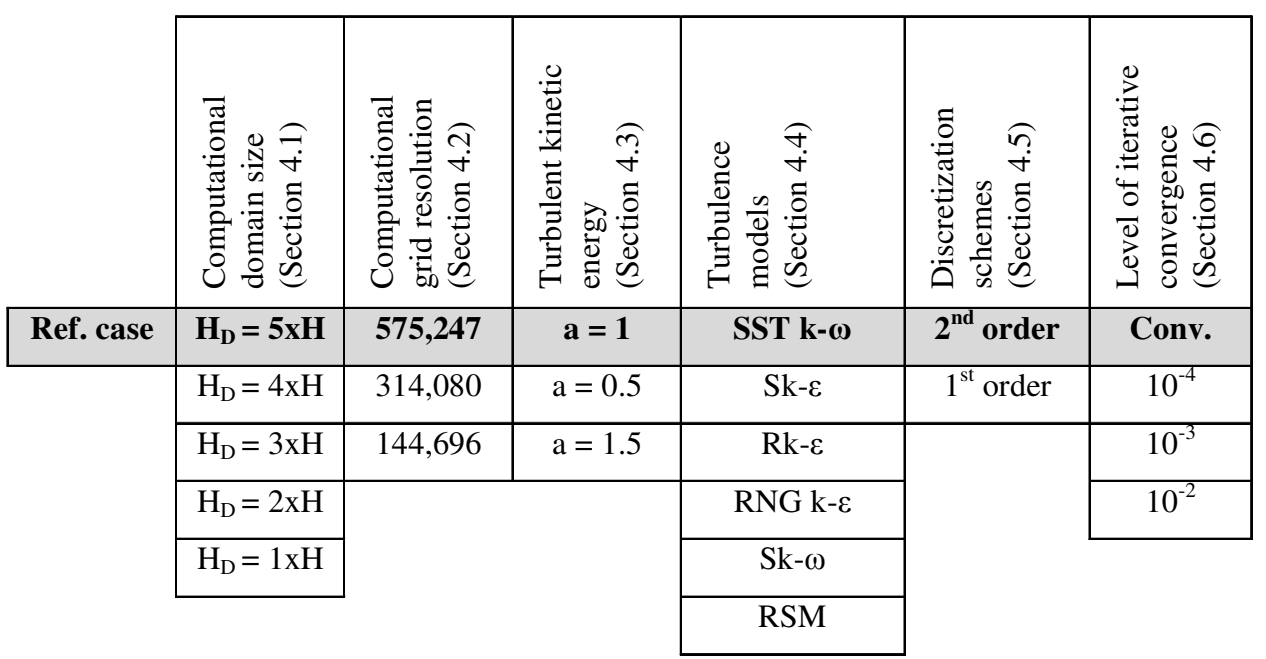

